\title{
PML: Regulation and multifaceted function beyond tumor suppression
}

\author{
Kuo-Sheng $\mathrm{Hsu}^{1,3}$ and Hung-Ying $\mathrm{KaO}^{1,2^{*}}$ (1)
}

\begin{abstract}
Promyelocytic leukemia protein (PML) was originally identified as a fusion partner of retinoic acid receptor alpha in acute promyelocytic leukemia patients with the $(15 ; 17)$ chromosomal translocation, giving rise to PML-RARa and RARa-PML fusion proteins. A body of evidence indicated that PML possesses tumor suppressing activity by regulating apoptosis, cell cycle, senescence and DNA damage responses. PML is enriched in discrete nuclear substructures in mammalian cells with 0.2-1 $\mu \mathrm{m}$ diameter in size, referred to as alternately Kremer bodies, nuclear domain 10, PML oncogenic domains or PML nuclear bodies (NBs). Dysregulation of PML NB formation results in altered transcriptional regulation, protein modification, apoptosis and cellular senescence. In addition to PML NBs, PML is also present in nucleoplasm and cytoplasmic compartments, including the endoplasmic reticulum and mitochondria-associated membranes. The role of PML in tumor suppression has been extensively studied but increasing evidence indicates that PML also plays versatile roles in stem cell renewal, metabolism, inflammatory responses, neural function, mammary development and angiogenesis. In this review, we will briefly describe the known PML regulation and function and include new findings.
\end{abstract}

Keywords: PML, Gene expression, Protein modification, Proteolysis, Stem cell and cancer stem cell renewal, Chemotherapy resistance, Metabolism, Inflammatory responses, Neural function, Mammary development, Angiogenesis

\section{Background}

Promyelocytic leukemia protein (PML) was first identified as a fusion partner with retinoic acid receptor alpha resulting from a chromosomal translocation between chromosomes 15 and 17 [1-3]. Since then, evidence has accumulated that PML functions as a tumor suppressor $[4,5]$. In mammalian cells, PML is enriched in discrete nuclear substructures referred to PML nuclear bodies (NBs) [6, 7]. In addition to PML NBs, PML is also present in the nucleoplasm and the cytoplasmic compartments, including the endoplasmic reticulum (ER) and mitochondria-associated membranes (MAMs) [8, 9]. It appears that both nuclear and cytoplasmic PML can promote cell apoptosis by distinct mechanisms $[8,10,11]$.

\footnotetext{
*Correspondence: hxk43@cwru.edu

${ }^{1}$ Department of Biochemistry, Case Western Reserve University, 10900 Euclid Avenue, Cleveland, OH 44106, USA

Full list of author information is available at the end of the article The original version of this article was revised: due to a display error in Table 3. For further details please read the correction connected to this article.
}

As a tumor suppressor, PML protein abundance is frequently low in tumorous tissues [12]. Thus, the regulation of $P M L$ gene expression, PML protein modification and turnover have been the main subjects of study. For exple, PML protein modifications, PML NB formaon, abundance and localization are tightly regulated response to environmental stimuli. Dysregulation of L and PML NB formation alter PML-associated tranand cellular senescence [13].

Due to its initial association with cancer as a tumor suppressor, early studies on PML have mainly focused on its role in apoptosis, cell cycle regulation and tumorigenesis [11]. Nonetheless, recent reports have indicated that PML plays versatile roles in other physiological and pathological settings. These include stem cell and cancer stem cell renewal, drug-resistance, metabolism, inflammatory responses, neural and mammary development and angiogenesis (see below). Together, these findings not only open a new avenue for understanding PML biology but 
they further highlight the possibility of targeting PML as a potential therapeutic strategy.

\section{PML protein structure and isoforms}

The PML protein belongs to the family of tripartite motif (TRIM)-containing proteins that consist of more than 70 members in humans characterized by a structurally conserved RING finger/B box/coiled-coil (RBCC) domain [14]. This RBCC motif is preserved among all PML isoforms [15] (Fig. 1). The RBCC domain has been shown to mediate protein-protein interactions and PML NB assembly [16-18]. The nascent $P M L$ transcript contains 9 exons (Fig. 1a) and can be alternatively spliced into multiple isoforms with variable C-termini. According to classical Jassen nomenclature, PML isoforms can be generally classified into PMLI to PMLVII (Fig. 1b). The nuclear localization sequence (NLS) in exon 6 is not present in the $P M L$ isoform VII, which is exclusively cytoplasmic $[15,19]$ (Fig. 1b). The largest isoform, PML I, harbors a putative nuclear export signal in the exon 9. Presumably, this isoform is capable of shuttling between nucleus and cytoplasm. In exon 7, a tetrapeptide sequence containing amino acids VVVI is known as a SUMO-interacting motif (SIM), due to its ability to bind sumoylated proteins [20]. Furthermore, a group of sub-class PML variants [19], A, B and C, derived from PML isoform I-VI are documented due to the alternative splicing as shown in Fig. 1b.

\section{Subcellular distribution of PML}

In mammalian cells, 1-30 discrete PML NBs with a size of $0.2-1 \mu \mathrm{m}$ can be observed in each nucleus $[6,21]$. PML is an essential component of PML NBs. To date more than 170 proteins have been found to associate with PML constitutively or transiently [22]. The composition of PML NBs is dynamic and heterogeneous due to the shuttling of PML-associated components and the composition of PML NBs is dictated by specific PML isoforms [7]. It was proposed that sumoylation of PML and SIM-dependent association with sumoylated proteins

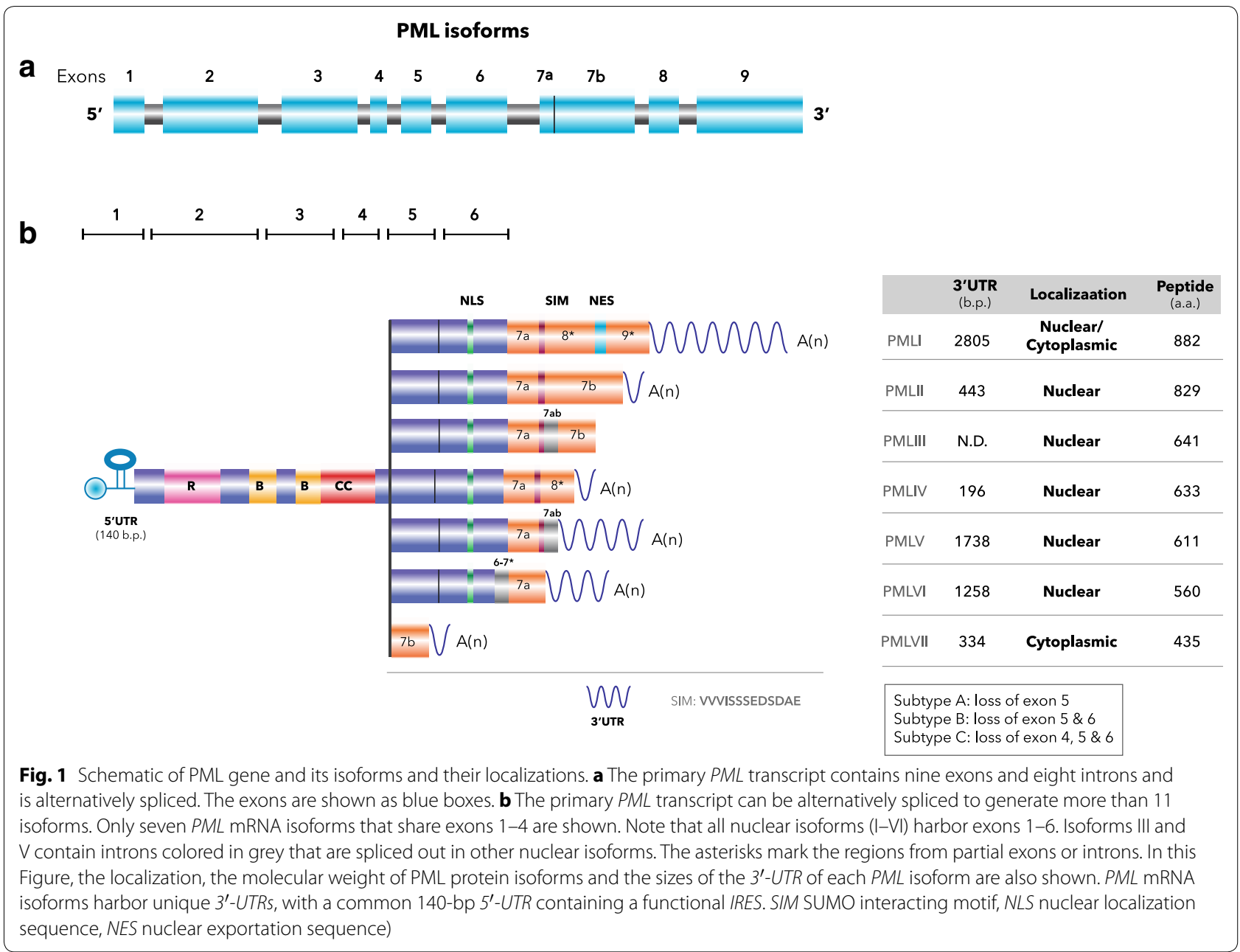


play a pivotal role in PML NB formation [23]. However, it is clear that sumoylation is not essential for NB formation because a mutant PML (3KR) devoid of sumoylation is still capable of forming NB, though the NB size is generally larger and the number is reduced [24]. PML NB assembly is likely initiated from PML oligomerization, though the residues responsible for the oligomerization remain to be identified [7, 13]. Given that PML-associated components harbor diverse physiological functions, the regulation of PML NBs is key to controlling various biological processes, such as apoptosis, inflammation and angiogenesis (see below).

In addition to localizing to the nucleus, several PML isoforms can be found in the cytoplasm. PML VII and PML I, as well as other isoforms, like subtype B and C, are potentially cytoplasmic due to the absence of the NLS or the inclusion of the NES (Fig. 1) [8, 19, 25]. Moreover, the truncated PML proteins caused by two distinct pathological missense mutations 1272delAG and IVS3-1 G are localized primarily in the cytoplasm and can sequester nuclear PML, thereby decreasing PML NBs [26]. Interestingly, cytoplasmic PML may possess opposite physiological functions from its nuclear counterpart, depending on the context. The 1272delAG and IVS3-1 G mutant cytoplasmic PMLs show dominant effects over nuclear PML and thereby inhibit p53-mediated transcription and cell growth suppression [26]. In response to HSV-1 infection, cytoplasmic PML is induced by increased alternative splicing, which presumably is part of the strategy employed by viruses to weaken host defenses [27]. A change in cellular redox status also alters cytoplasmic PML levels by redistributing nuclear PML to the cytoplasm. For example, treatment with the antioxidant, sulforaphane in HUVECs results in an accumulation of PML in the cytoplasm [28]. In another example, TGF $\beta$ stimulation, cytoplasmic PML or PML VII, exclusively cytoplasmic isoforms recruit Smad2/3 and SARA to potentiate TGF $\beta$ signals, cell growth arrest, senescence, and apoptosis [8]. A fraction of PML in mouse embryonic fibroblasts (MEFs) was found localized in MEMs which bridge mitochondria and the ER. Such MEM-associated PML controls calcium flux to the mitochondria by compartmentalizing a large complex that includes PP2A, AKT, and the inositol triphosphate receptor (IP3R) [10]. Given that calcium influx into mitochondria from the ER is a key step in apoptosis, $\mathrm{Pml}^{-1-}$ MEFs exhibit resistance to ER stressinduced apoptosis. Thus, PML appears to be a critical regulator of apoptosis both in the nucleus and the cytoplasm [10].

\section{Regulation of PML expression by multiple extracellular stimuli}

PML is a sensor of cellular stress and environmental cues including growth factors and cytokines. The abundance of PML protein is tightly regulated by transcriptional and translational machineries in response to stresses.
Additionally, post-translational modification plays a key role in PML regulation and has been intensely studied. Modification of PML disturbs PML NB assembly and alters PML protein stability, localization and interaction partners. Several key regulatory mechanisms for PML are summarized in Tables 1, 2 and Fig. 2.

\section{Transcriptional and translational control of PML}

Transcriptional regulation of PML is a critical mechanism for cells to respond to environmental changes. All interferons (IFNs) have been shown to induce $P M L$ mRNA and protein levels and consequently increase the size and number of PML NBs [29]. Transcriptional up-regulation of PML mRNA by IFNs is mainly mediated by the IFN downstream transcription factors, signal transducers and activators of transcription (Stats) and their cis-elements in the $P M L$ promoter, including IFN-stimulated response elements (ISRE; -GAGAATCGAAACT-) and gammaactivated sites (GAS; -TTTACCGTAAG-) [30]. These IFN responsive cis-elements are activated by both type I and type II IFNs. However, deletion of the GAS element from the promoter only attenuates cellular response to type II IFNs [30]. Also, the interferon-induced regulatory factors, IRF3 and IRF8, are found to bind either ISRE or GAS element and activate $P M L$ transcription [31]. In addition to promoter-driven transcriptional regulation, p53 can bind the $P M L$ coding region and when overexpressed, up-regulates $P M L$ transcription [32]. Through a similar mechanism, RAS-induced p53 up-regulates PML and subsequently promotes cellular oncogenic senescence [33]. Conversely, Stat 3 and Stat6 suppress $P M L$ expression during mammary gland development [34].

PML expression is also subjected to regulation by several post-transcriptional mechanisms. Alternative splicing of $P M L$ primary transcripts gives rise to multiple $P M L$ isoforms, all of which possess unique $3^{\prime}-U T R s$ (Fig. 1b). A recent finding suggests that mir-1246 targets $P M L I$ mRNA and reduces its accumulation [35]. In contrast, overexpressed $K-R A S$ enhances translation of $P M L$ mRNA in a manner that is mTOR/eIF4E- and $P M L$ 5 '-UTR-dependent [36]. During our investigation on the mechanism by which TNF $\alpha$ induces PML protein levels, we identified a well-conserved, 100-nt internal ribosome entry site (IRES) upstream of the translation initiation site. This IRES is further activated by the p38-MNK1 axis to increase PML protein synthesis [37].

\section{Post-translational modification and subsequent effects on PML protein turnover, ubiquitination (Ub) and Ub-like protein modification}

PML protein is covalently conjugated to small protein modifiers, including ubiquitin, SUMO, and possibly ISG15. These modifications require distinct E1/E2/ 
Table 1 Summary of factors and conditions involved in PML transcription, translation, alternative splicing and subcellular distribution

\begin{tabular}{|c|c|c|c|c|}
\hline Type of regulation & Extracellular stimuli & Cellular regulators & PML regulation & Refs. \\
\hline \multicolumn{5}{|l|}{ Transcription } \\
\hline & IFNs, TNFa & Stat1 and Stat2/IRF3/IRF8 & Upregulation of $P M L$ mRNA & {$[29-31,109]$} \\
\hline & Oncogenic stress & RAS/p53 & Upregulation of $P M L$ mRNA & {$[32,33]$} \\
\hline & Cytokine or hormone & Stat3/Stat6 & Downregulation of $P M L$ transcription & {$[34]$} \\
\hline \multicolumn{5}{|l|}{ Post-transcription } \\
\hline Alternative splicing & & & $\begin{array}{l}\text { Expression of different PML isoforms with } \\
\text { distinct function }\end{array}$ & {$[15,20]$} \\
\hline Alternative splicing & Herpes simplex virus-1 infection & & $\begin{array}{l}\text { Increase in cytoplasmic PML in response } \\
\text { to viral infection }\end{array}$ & {$[27]$} \\
\hline mRNA stability & $\begin{array}{l}\text { MicroRNAs delivered by colon cancer } \\
\text { cell-derived microvesicles }\end{array}$ & miR-1246 & Targeting PML 3'-UTR for degradation & {$[35]$} \\
\hline \multicolumn{5}{|l|}{ Translation } \\
\hline & Oncogenic stress & $\begin{array}{l}\text { RAS/mTOR } \\
\text { RAS/elF4E }\end{array}$ & $\begin{array}{l}\text { Upregulation of Pm/ mRNA translation } \\
\text { 5'-UTR in MEFs }\end{array}$ & {$[36]$} \\
\hline & TNFa & p38/MNK1 & $\begin{array}{l}\text { Upregulation of PML mRNA translation } \\
\text { via IRES }\end{array}$ & [37] \\
\hline \multicolumn{5}{|c|}{ Cytoplasmic PML regulation } \\
\hline & TGF $\beta$ & TGFR & $\begin{array}{l}\text { Smad } 2 / 3 \text { and SARA-mediated TGF } \beta \\
\text { signaling }\end{array}$ & {$[8]$} \\
\hline & Sulforaphane (SFN) & & $\begin{array}{l}\text { Increases in cytoplasmic PML proportion } \\
\text { and nuclear NRF2 accumulation }\end{array}$ & {$[28]$} \\
\hline & $\begin{array}{l}\text { PML 1272delAG and IVS3-1 G muta- } \\
\text { tions }\end{array}$ & & $\begin{array}{l}\text { Increases in cytoplasmic PML proportion } \\
\text { and inhibition of p53-mediated cell } \\
\text { apoptosis }\end{array}$ & {$[26]$} \\
\hline \multicolumn{5}{|l|}{ NB formation } \\
\hline & Androgen & & Decreases in PML NB formation & {$[160]$} \\
\hline & lonizing radiation & & Increases in PML NB formation & {$[161]$} \\
\hline & Cisplatin & & Increases in PML NB formation & [161] \\
\hline & SFN & & Decreases in PML NB formation & {$[28]$} \\
\hline
\end{tabular}

The abundance/activity of PML protein can be regulated at the level of transcription, alternative splicing, translation and subcellular distribution. The types of regulation are listed in the first column; the extracellular agent or stress that contributes to the PML regulation is summarized in the second column; regulation factors that target or modify PML are shown in the third column and the final column describes effects of these regulatory factors on PML regulation

E3 ligation systems. Three lysine residues, K65, K160 and $\mathrm{K} 490$, have been identified as the major sumoylation sites [38]. Four SUMO family proteins, including SUMO1, SUMO2, SUMO3 and SUMO5 are known to modify PML at different lysines and sumoylation at different lysine residues has distinct functional consequences [38, 39]. Given that the sumoylation of PML is important for protein-protein interactions, a mechanism underlying sumoylation-dependent biogenesis of PML NBs has been proposed [7, 40]. However, mutations at the three major sumoylation sites reduce but do not completely abolish PML NB formation [24]. Three SUMO E3 ligases, RanBP2, PIAS1 and ZNF451-1 have been suggested to promote PML sumoylation at K490 and K65/ K160, respectively [41-44]. Additionally, HDAC7 harbors sumoylation E3 ligase-like activity and promotes PML sumoylation by a HDAC activity-independent manner [45]. Interestingly, loss of RanBP2 and $H D A C 7$ significantly reduces the size and number of PML NBs, while knockdown of PIAS1 increases PML NBs [42-45]. Several pathways or factors have been found to promote PML desumoylation including the SUMO-specific protease (SENP) family. Of this family, all of the SENPs, except SENP4, are capable of removing SUMO conjugation from PML, thus contributing to the dynamic change of PML NBs [46-50]. DNA damage agents and oxidative stress inducers such as arsenic trioxide $\left(\mathrm{As}_{2} \mathrm{O}_{3}\right)$ also regulate PML sumoylation and PML NB maturation [6, 51, 52]. $\mathrm{As}_{2} \mathrm{O}_{3}$ has been reported to promote NB formation by directly oxidizing PML cysteine residues and by inducing intracellular ROS production, thus facilitating PML sumoylation and degradation [53, 54].

PML protein abundance is regulated by Ub-mediated turnover through multiple mechanisms. Several E3 ligases have been identified that promote PML poly-ubiquitination. As a PML bona fide ubiquitin E3 
Table 2 Summary of signaling involved in PML post-translational modification

\begin{tabular}{|c|c|c|c|c|}
\hline $\begin{array}{l}\text { Type of post-translational } \\
\text { modification }\end{array}$ & Extracellular stimuli & Cellular factors & PML regulation & Refs. \\
\hline \multicolumn{5}{|l|}{ Sumoylation (site) } \\
\hline \multirow[t]{2}{*}{ K65/K160/K490 } & ND & RanBP2 /Ubc9 & Assembly of PML NBs & {$[20,38,42,43,61,162]$} \\
\hline & ND & ZNF451-1 & $\begin{array}{l}\text { Increases in RNF4-mediated PML } \\
\text { degradation }\end{array}$ & [41] \\
\hline K65 and K160 & $\mathrm{As}_{2} \mathrm{O}_{3}$, Tumorigenic adaptation & PIAS1 & $\begin{array}{l}\text { Increases in CKII-mediated PML deg- } \\
\text { radation }\end{array}$ & {$[44]$} \\
\hline ND & Cell cycle & ND & Oscillation of PML sumoylation status & {$[163]$} \\
\hline $\mathrm{K} 65 / \mathrm{K} 160$ & $\mathrm{As}_{2} \mathrm{O}_{3}$ & & $\begin{array}{l}\text { Sumoylation and sumoylation-medi- } \\
\text { ated ubiquitination and degradation }\end{array}$ & [51] \\
\hline ND & TNFa & HDAC7 & Upregulation of sumoylation & {$[45,84]$} \\
\hline ND & Thermal stress/Cellular stress & SENP & Desumoylation/NBs dynamic & {$[44,46-50]$} \\
\hline K65/K160 & Viral infection & LANA2 & $\begin{array}{l}\text { Upregulation of SUMO2-conjugated } \\
\text { sumoylation }\end{array}$ & [164] \\
\hline ND & Epstein-Barr virus infection & BZLF1 & PML desumoylation and NB breakdown & {$[124]$} \\
\hline ND & Cytomegalovirus infection & $\mathrm{IE} 1$ & Disruption of PML NBs & [126] \\
\hline \multicolumn{5}{|l|}{ Phosphorylation (site) } \\
\hline ND & DNA damage & ATR & Nucleolar localization & {$[6,52,67]$} \\
\hline S565 & Osmotic stress/Cellular stress & CKII & PML degradation & [73] \\
\hline S518 & Hypoxia & $\mathrm{CDK} 1 / 2$ & $\begin{array}{l}\text { Increases in KLHL20-meidated PML } \\
\text { ubiquitination and degradation }\end{array}$ & {$[58]$} \\
\hline ND & Cell cycle & Aurora kinase A & PML hyper-phosphorylation & {$[72]$} \\
\hline S403 and S505 & EGF, oncogenic adaptation & ERK2 & $\begin{array}{l}\text { Increases in Pin 1-mediated PML deg- } \\
\text { radation }\end{array}$ & {$[70,71]$} \\
\hline S527 and S530 & $\mathrm{As}_{2} \mathrm{O}_{3}$ & ERK $1 / 2$ & $\begin{array}{l}\text { Increases in PML sumoylation and PML- } \\
\text { mediated apoptosis }\end{array}$ & {$[69]$} \\
\hline S117 & $\gamma$-irradiation & Chk2 & Increases in PML-mediated Apoptosis & {$[66]$} \\
\hline $\mathrm{S} 8, \mathrm{~S} 36$, and $\mathrm{S} 38$ & DNA damage & HIPK2 & Increases in PML-mediated Apoptosis & {$[68]$} \\
\hline S403 and T409 & Mitogenic stimuli & BMK1/ERK5 & $\begin{array}{l}\text { Inhibition of PML-mediated p21 sup- } \\
\text { pression for cancer cell proliferation }\end{array}$ & [165] \\
\hline S518 & ND & SCP1/SCP3 & $\begin{array}{l}\text { Blockade of CDK1/2-Pin 1-KLHL20-PML } \\
\text { regulatory loop and PML-mediated } \\
\text { anti-angiogenesis }\end{array}$ & [153] \\
\hline \multicolumn{5}{|l|}{ Ubiquitination } \\
\hline & $\mathrm{As}_{2} \mathrm{O}_{3}$ & E6AP & PML degradation & {$[55,56]$} \\
\hline & ND & $\mathrm{SIAH} 1$ and $\mathrm{SIAH} 2$ & PML degradation & {$[57]$} \\
\hline & ND & UHRF1 & PML degradation & {$[166]$} \\
\hline & Hypoxia & KLHL20 & PML degradation & {$[58]$} \\
\hline & $\mathrm{As}_{2} \mathrm{O}_{3}$ & RNF4 & $\begin{array}{l}\text { Catalyzing sumoylation-dependent } \\
\text { degradation, increase in PML NB } \\
\text { formation }\end{array}$ & {$[51,53,54]$} \\
\hline & HSV-1 infection & ICPO & PML degradation & [125] \\
\hline & $\mathrm{As}_{2} \mathrm{O}_{3}$ & RNF111 (Arkadia) & $\begin{array}{l}\text { Catalyzing sumoylation-dependent } \\
\text { degradation }\end{array}$ & {$[59]$} \\
\hline \multicolumn{5}{|l|}{ Isgylation } \\
\hline & Retinoic acid & UBE1L/USP18 & PML-RAR degradation & {$[62,63,167]$} \\
\hline \multicolumn{5}{|l|}{ Acetylation (site) } \\
\hline K487 and K515 & ND & p300 & Increases in PML sumoylation & {$[74]$} \\
\hline K487 & $\mathrm{H}_{2} \mathrm{O}_{2}$ & Sirt1/Sirt5 & $\begin{array}{l}\text { Deacetylation of PML, increase in K490 } \\
\text { sumoylation }\end{array}$ & {$[75,77]$} \\
\hline K487 & ND & Sirt1 & $\begin{array}{l}\text { Promotion of PML/PER2-induced } \\
\text { BMAL1/CLOCK transcriptional activity }\end{array}$ & {$[76]$} \\
\hline
\end{tabular}


Table 2 continued

\begin{tabular}{|c|c|c|c|c|}
\hline $\begin{array}{l}\text { Type of post-translational } \\
\text { modification }\end{array}$ & Extracellular stimuli & Cellular factors & PML regulation & Refs. \\
\hline \multicolumn{5}{|l|}{ Protein level regulation } \\
\hline & $\mathrm{H}_{2} \mathrm{O}_{2}$ & Pin1 & $\begin{array}{l}\text { Decreases in Pin 1-PML association and } \\
\text { Pin1-mediated PML degradation }\end{array}$ & {$[71]$} \\
\hline & IGF-1, hypoxia & Pin1 & $\begin{array}{l}\text { Increases in Pin1-PML association and } \\
\text { Pin1-mediated PML degradation }\end{array}$ & [108] \\
\hline
\end{tabular}

Post-translational modification of PML controls multiple PML properties, such as protein-protein interaction, stability, NB formation and its ability to regulate transcription and apoptosis. The types of PML post-translational modification and modification sites are listed in the first column; the extracellular agent or stress that contributes to the PML post-translational modification is summarized in the second column; regulation factors that target or modify PML are shown in the third column and the final column describes effects of these regulatory factors on PML post-translational modification

ND Not determined

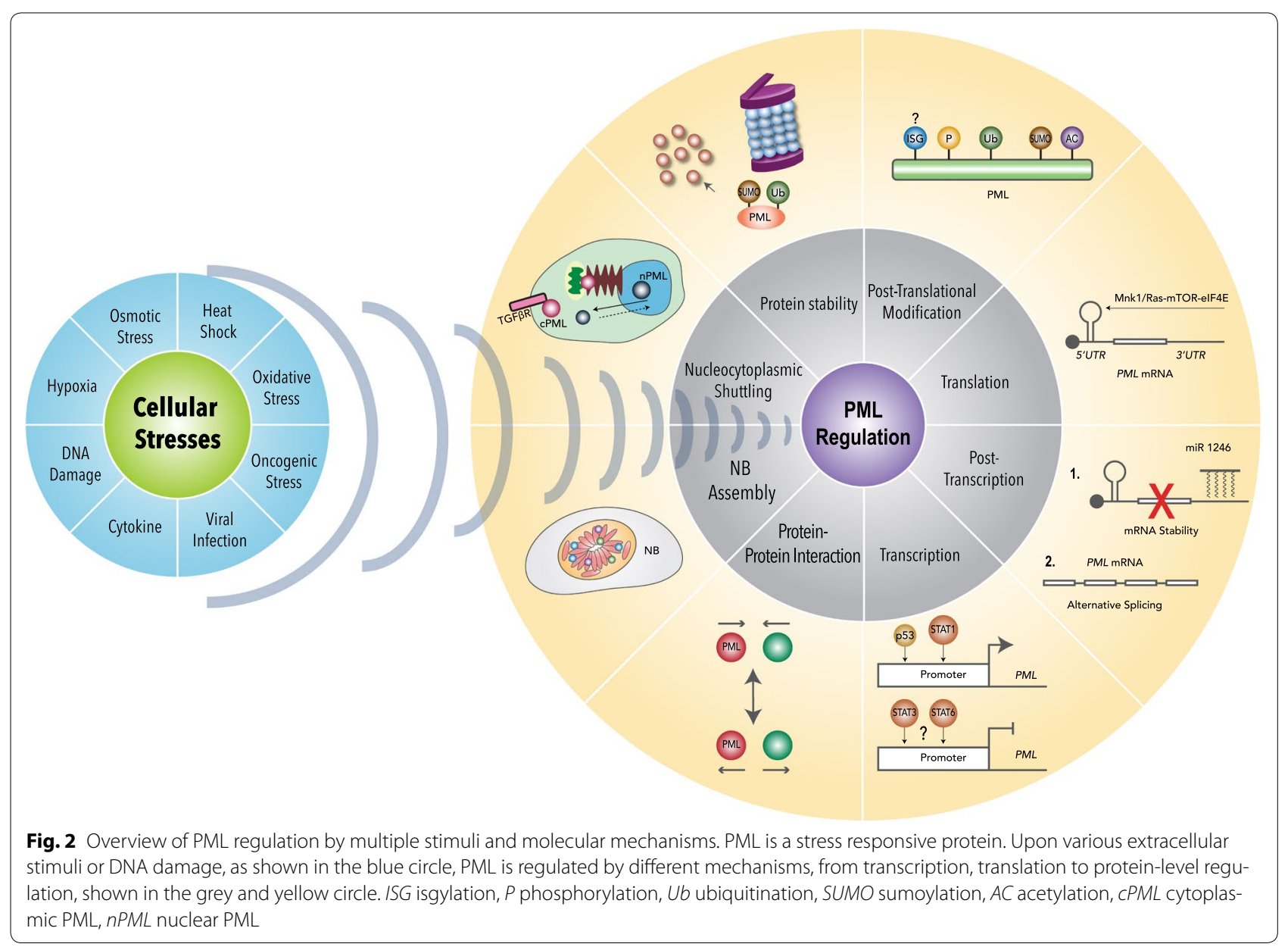

ligase, E6AP interacts with PML and overexpression of E6AP promotes PML poly-ubiquitination and degradation [55]. Partial depletion of E6AP in lymphoid cells results in an accumulation of PML protein and thereby enhances cell susceptibility to genotoxic stress-induced cell death $[55,56]$. Similarly, RING-finger ubiquitin E3 ligases, SIAH1 and SIAH2, interact with the PML RING domain and overexpression of these two proteins results in PML and PML-RAR $\alpha$ degradation in a proteasomedependent manner [57]. Under hypoxic conditions, the hypoxia transcription factor HIF1 $\alpha$ upregulates KLHL20, an E3 subunit, which promotes degradation of PML in 
a CDK2- and Pin1-dependent manner, thus promoting prostate cancer progression [58]. Notably, the RNF E3 ubiquitin ligase family in mammalian cells, including RNF4 and RNF111, contains a SUMO interacting motif [59]. In $\mathrm{As}_{2} \mathrm{O}_{3}$ treated APL cells, the SUMO ligase PIAS1 promotes PML sumoylation and facilitates the recruitment of RNF4/RNF111 to PML for poly-ubiquitination and degradation $[59,60]$. Through the C-terminal SIM, PML also can interact with sumoylated proteins, including PML itself [20, 38, 61].

It has also been suggested that PML can be modified by ISG15 conjugation (Isgylation). This SUMO-like small protein is induced by type I interferons, lipopolysaccharide or viral infection. Retinoic acid (RA) induced expression of the E1-like ubiquitin-activating enzyme (UBE1L), which enhances ISG15 conjugation of the PML domain of PML/RAR $\alpha$, causing its degradation $[62,63]$. Consistently, down-regulation of the ISG15 deconjugating enzyme, USP18, results in an increased fraction of isgylated PML-RAR $\alpha$ which leads to a decrease in PMLRAR $\alpha$ protein levels, and subsequent APL cell apoptosis [64]. In summary, isgylation of PML may contribute to the PML degradation process.

\section{Phosphorylation}

A major function of PML phosphorylation is to regulate PML protein turnover and PML NB formation, in response to extracellular stimuli such as growth factors and stress conditions such as mitogens, DNA damage and oncogenic stress [65]. When cells are confronted with DNA damage, UV exposure or double stand breaks, PML NBs initially go into a forced fission state because of topological changes of chromatin and hence increase the overall number of small NBs, called PML microbodies [52]. In the late phase of DNA damage repair (DDR), these PML microbodies are thought to assist in the repair process and their propagation is regulated by the DNA checkpoint kinases, Chk2, ATM and ATR. Thus, PML appears to be a sensor and mediator of DNA damage [52]. Furthermore, in response to $\gamma$-irradiation, Chk2 phosphorylates PML at S117, thus promoting apoptosis [66]. During doxorubicin induced DNA damage, PML is phosphorylated by the ataxia telangiectasia $\operatorname{Rad}-3$ related kinase (ATR) and accumulates in nucleoli where it sequesters the p53 ubiquitin ligase MDM2, resulting in p53 stabilization [67]. In Adriamycin-induced DNA damage, HIPK2 induces PML phosphorylation at serine 8 and 38, followed by PML sumoylation, stabilization and ensuing apoptosis [68]. Similarly, several ERK1/2 phosphorylation sites on PML have been identified and ERK2mediated PML phosphorylation has been shown to increase PML sumoylation in response to $\mathrm{As}_{2} \mathrm{O}_{3}$-induced apoptosis [69]. In addition, S403 and S505 of PML are phosphorylated by ERK2 and are essential for Pin1induced PML degradation [70, 71]. In response to hypoxia, CDK1/2 phosphorylates PML at S518 and promotes Pin1-mediated, cullin3-KLHL20-dependent PML poly-ubiquitination and degradation in prostate cancer cells [58]. Given that PML protein levels oscillate during the cell cycle, besides CDK1/2, another cell cycle related kinase, Aurora kinase A can also phosphorylate PML at several serine residues, implying that phosphorylation of PML may be involved in cell cycle control [72]. Lastly, cellular stresses, such as DNA damage and osmotic stress, promote CK2-mediated PML phosphorylation, leading to PML poly-ubiquitination and degradation promoting cell survival [73].

\section{Other modifications}

Using the HDAC inhibitor TSA, it was shown that PML is acetylaed at two lysine residues, $\mathrm{K} 87$ and $\mathrm{K} 515$ by $\mathrm{p} 300$ [74]. This acetylation can be removed by the class III deacetylase, Sirt1 [75] and Sirt5. K487 is the major acetylated residue and PML deacetylation by Sirt1 promotes PMLmediated PER2 nuclear localization, thus enhancing PER2-mediated circadian gene expression [76]. Furthermore, high concentrations of hydrogen peroxide $\left(\mathrm{H}_{2} \mathrm{O}_{2}\right)$, an oxidative stress inducer, promotes PML nuclear localization and sumoylation at K490, doing so by recruiting Sirt1 and Sirt5 to catalyze K487 deacetylation [77]. Reciprocally, a loss of SIRT1 or SIRT5 by shRNA knockdown induces $\mathrm{K} 487$ acetylation, reduces $\mathrm{K} 490$ sumoylation and attenuates $\mathrm{H}_{2} \mathrm{O}_{2}$-induced cell death. Thus, $\mathrm{K} 487$ acetylation and K490 sumoylation are mutually exclusive. Such regulation may not be limited to PML.

\section{Regulation of cellular processes by PML Regulation of transcription by PML}

PML has Ying-Yang effects on the regulation of transcription, but the underlying mechanism remains unclear. Although Chromatin immunoprecipitation (ChIP)-PCR studies have shown that PML can be recruited to promoter regions $[78,79]$, it is not clear whether nucleoplasmic PML or PML in NBs associates with chromatin and how PML can regulate transcription negatively and positively. This issue is critically important because PML NBs are cellular sensors and their assembly and disassembly are tightly regulated by redox and nutrients [80]. However, this issue is also difficult to address, in part, because there was no available mutant that distinguishes between PML in the nucleoplasm and in NBs. Several observations support the model in which PML regulates transcription through its ability to sequester transcription factors in PML NBs and block their access to chromatin. For example, many transcription factors including the transcriptional coactivator, histone acetyltransferase CBP 
and transcriptional corepressor proteins Ski and N-CoR are found to colocalize with PML in NBs, often in a signal-dependent manner [13, 81]. The corepressor Daxx is sequestered by PML NBs from repressing GR [82] and Pax3 [83] target genes in response to $\mathrm{As}_{2} \mathrm{O}_{3}$ treatment. Induction of PML NBs by TNF $\alpha$ can sequester nuclear HDAC7 and derepress HDAC7-mediated gene repression in HUVECs $[45,84]$. Under conditions of cellular senescence, the induction of PML NBs by oncogenic RAS (RasV12) redirects RB-E2F complexes into heterochromatic regions and blocks E2F activation, thus facilitating senescent processes [78]. Consistent with the sequestration model, PML NBs contain neither chromatin nor nascent RNAs, suggesting that they are not directly involved in transcription [21]. However, immunohistochemistry and microscopic studies suggest that PML NBs physically associate with chromatin $[85,86]$. So far, there is no clear evidence to rule out or conclude that PML NBs may directly involve in transcription regulation.

\section{Regulation of mRNA translation by PML}

PML is capable of sequestering the translation initiator eIF4E in the nucleus, thus blocking nuclear export of eIF4E-associated mRNAs and their subsequent polypeptide synthesis $[87,88]$. In cap-dependent protein synthesis, the translation initiator eIF4E binds to the $5^{\prime} \mathrm{m}^{7} \mathrm{G}$ cap of most mRNAs that are poised to be translated in the cytoplasm. However, an estimated $70 \%$ of cellular eIF4E is localized in the nucleus and this observation intuitively raises a question of whether eIF4E has other functions [89]. Indeed, through binding to structurally conserved $3^{\prime}-U T R$ elements in some capped mRNAs, including cyclin D1 and Pim1, nuclear eIF4E facilitates export of these mRNAs to the cytoplasm [87]. The interaction between PML and eIF4E in the nucleus attenuates eIF4E binding to eIF4E-sensitive mRNAs and blocks their nuclear export, thereby lowering protein synthesis of these mRNAs [87]. Furthermore, other translation factors, such as eIF3 and eEF1A1, have been reported to interact with PML. Despite the biochemical interaction of PML with multiple translation factors, it is still unclear whether PML directly regulates ribosome loading or participates in the peptide synthesis [90].

\section{Regulation of protein post-translational modifications and protein-protein interactions by PML}

Since PML associates with several protein modification enzymes, the dynamics of PML NBs have been shown to play a role in protein phosphorylation, sumoylation, ubiquitination and acetylation [13]. HIPK2, p53 and CBP are recruited to PML NBs in response to ultraviolet radiation and this recruitment facilitates HIPK2-mediated p53 phosphorylation and ensuing p53 acetylation by CBP and subsequent p53-mediated apoptosis [91, 92]. The acetylation and deacetylation of p53 is dynamically regulated in PML NBs. Sirt1 serves as a deacetylase to balance p53 acetylation. Overexpression of Sirt 1 promotes p53 de-acetylation, which represses p53-mediated transactivation, consequently antagonizing PML-mediated cell senescence [93].

PML also enhances dephosphorylation of a subset of proteins. For example, loss of $\mathrm{Pml}$ in mouse neural progenitor cells results in mis-localization of protein phosphatases 1A (PP1A), 2A (PP2A) and RB, which leads to $\mathrm{RB}$ hyper-phosphorylation, cell proliferation and dysregulation of neuronal development [94]. Loss of Pml also blocks PP2A-mediated nuclear AKT dephosphorylation, enhances AKT activity and exacerbates AKTinduced tumorigenesis in $\mathrm{Pten}^{+-}, \mathrm{Pml}^{-/-}$mice [4]. Upon genotoxic stress, IKKe translocates to the nucleus and is recruited to PML NBs, where IKKe is sumoylated by PML-associated SUMO E3 ligase, TOPORS and the sumoylated IKKe is capable of phosphorylating NFkB subunit p65 and contributes to the anti-apoptotic function of NFkB [95].

Some PML-associated protein-protein interactions are sumoylation-dependent through its C-terminal SIM [20, $40,96,97]$. Through this interaction, several sumoylated proteins can be recruited to PML NBs. For example, $\mathrm{As}_{2} \mathrm{O}_{3}$ induces sumoylation of the antioxidant response transcription factor, NRF2, recruitment to the PML NBs and degradation by RNF4-mediated proteolysis [98]. Furthermore, under osmotic stress, CK2-induced Daxx sumoylation enhances its association with PML and promotes Daxx-mediated anti-apoptotic gene repression [97]. Noticeably, in addition to serving as a platform for SUMO conjugation and protein-protein interactions, PML also directly sumoylates its substrates, such as p53, MDM2 and nuclear misfolded proteins [99, 100]. Chu and Yang have characterized at least seven members of TRIM family proteins, including PML, as potential SUMO E3 ligases which promote MDM2 sumoylation in vivo [99]. Furthermore, the in vitro sumoylation of MDM2 and p53 using recombinant PML protein demonstrates PML as a bona fide SUMO E3 ligase [99]. The structural integrity of conserved RING and B-box domains in PML appears required for a full SUMO ligase activity [99]. Since several TRIM proteins also possess ubiquitin E3 ligase activities and PML is highly associated with this conjugation, it will be interesting to investigate whether PML, like TRIM 27 functions as a dual SUMO and ubiquitin E3 ligase [99]. These findings highlight a potential important physiological and pathological function of PML SUMO ligase activity [100].

Several ubiquitin E3 ligases and deubiquitin enzymes have been found in PML NBs. In response to INF $\alpha$ and 
$\gamma$ stimulation, an increase in the number of PML NBs results in sequestration of the ubiquitin E3 subunit KLHL20 to NBs. This results in dissociation of KLHL20 from its substrate DNAPK and further enhancing DNAPK stabilization and DNAPK-mediated apoptosis and autophagy [101]. Additionally, upon doxorubicininduced DNA damage, PML blocks p53 poly-ubiquitination and degradation by sequestering the p53 ubiquitin E3 ligase, MDM2, to PML NBs [67]. Moreover, PML compromises de-ubiquitin enzyme HAUSP/USP7mediated PTEN deubiquitination by antagonizing Daxx, a positive regulator of HAUSP activity. Since PTEN mono-ubiquitination is a prerequisite for its nuclear retention and tumor suppressor functions [102], Pml knockout MEFs or PML dysfunction in APL cells results in PTEN de-ubiquitination and nuclear exclusion [102].

\section{Other cellular function of PML}

Through its association with the DDR kinases, ATR and HIPK2, PML is a regulator of DNA repair processes [52, $66-68,91,92]$. In addition to PML's nuclear function, recent findings demonstrated that cytoplasmic PML can regulate MAMs calcium release to mitochondria and consequently controls autophagy and apoptosis $[9,10]$. Also, cytoplasmic PML is involved in TGF $\beta$ signal activation [8]. Treatment with the antioxidant SFN in HUVECs reduces nuclear PML, thereby promoting ROS levels, NRF2 activation [28] and induction of antioxidant gene expression. As a cellular redox sensor, PML is a major regulator for redox homeostasis. In $\mathrm{Pml}^{-/-} \mathrm{MEFs}$ and mouse liver, the PML deficiency leads to a loss in essential proteins for mitochondrial complex II function, including Sdha-d, Sdhaf1 and Sdhaf2 and results in the dysfunction of mitochondria and ROS elevation [28]. These data suggest that PML is a key player capable of rebalancing cellular oxidoreduction status in response to different redox perturbations.

\section{Physiological and pathological role of PML PML plays a role in tumor suppression}

The tumor suppressor activity of PML was clearly demonstrated based on the higher incidence of tumor formation in Pml knockout mouse models [5]. In the context of $P m l$ deficiency, additional oncogenic mutations or tumor suppressor depletion significantly exacerbates tumor formation $[4,73]$. Consistent with the mouse studies, low PML expression is observed in several types of human cancers, further supporting PML as a guardian to prevent tumorigenesis $[12,103,104]$. In the past decades, a body of in vivo and in vitro studies have elucidated PML's function in the blockade of cell growth, cell migration and angiogenesis, thus strengthening a role of PML in the tumor suppression. The major findings are summarized as follows: (1) PML stabilizes the tumor suppressor protein $\mathrm{p} 53$ resulting in a positive feedforward loop to promote cell apoptosis and senescence [32, 105]; (2) PML also promotes p53-independent apoptotic pathways, including calcium release from ER and the induction of pro-apoptotic gene expression through sequestration of the transcription repressor, Daxx [10, 106]; (3) PML is transcriptionally and translationally up-regulated by oncogenic K-RAS and is required for K-RAS-induced cellular senescence [33, 36]; (4) PML is regulated by DNA-damage-responsive kinases ATR/Chk2 and is required for DNA damage-induced apoptosis [67]; (5) PML associates with telomeric DNA and telomerase, resulting in telomere instability-induced cell senescence [107]; (6) PML has the potential to suppress breast cancer cell and endothelial cell migration [37, 71, 108] and (7) PML negatively regulates tumor-associated angiogenesis as discussed later $[35,109,110]$.

The role of PML in the maintenance of hematopoietic stem cells and drug-resistance

Recent studies proposed that PML is implicated in the maintenance of cancer stem cells and in the promotion of anti-cancer drug resistance [111]. In glioma, treatment with therapeutic kinase inhibitor against PI3K, AKT or mTOR increased PML protein levels, which may contribute to drug resistance [112]. Therefore, targeting PML could be an approach to reduce the population of drug-resistant cancer cells. Indeed, knockdown of $P M L$ or treatment of glioblastoma cells with the PML degradation agent, arsenic trioxide, inhibited cancer stem cell growth as well as glioblastoma tumor growth in a mouse xenograft model [113]. The therapeutic potential of $\mathrm{As}_{2} \mathrm{O}_{3}$ on glioma is partially attributed to PML degradation which consequently leads to the PMLassociated C-Myc degradation [113]. Because C-Myc is preferentially expressed in cancer stem cells, treatment of PML-degradable agents is limited to the cancer stem cell population and not to matched non-stem cancer cells. In chronic myelogenous leukemia (CML) patients, PML expression levels are negatively correlated with prognosis outcomes. Utilizing a classical p $210^{\mathrm{BCR}-\mathrm{ABL}}$ mouse leukemia model, Ito et al. showed that depletion of $P m l$ in $210^{\mathrm{BCR}-\mathrm{ABL}}$-positive leukemic cells was unable to establish CML-like phenotype after serial bone marrow transplantation [114]. PML does so by up-regulating PPAR $\delta$, a master transcription factor that regulates fatty acid metabolism by modulating fatty acid oxidation gene expression. Thus, it was concluded that the PML-PPAR $\delta$ Fatty acid oxidation (FAO) axis promotes asymmetric division of HSC, a key step keeping stem cell self-renewal from HSC exhaustion [114]. PML also plays a key role in maintaining progenitor cell quiescence and preserving 
progenitor cell pluripotency, thus contributing to normal mammary gland and neuron development [34, 94]. Also, a PML-PGC1-PPAR $\alpha$-mediated FAO increase was recapitulated in breast cancer stem cells. It was hypothesized that the breast cancer stem cells escape apoptosis and use ATP produced by FAO as an energy resource for survival [115]. Together, these observations suggest that PML is a key regulator of self-renewal for some types of stem cells and stem-like cancer cells [113-115].

\section{PML function in physiological metabolism}

In a recent study, Ohsaki and Fujimoto et al. identified a novel function of nuclear PML in the biogenesis of nuclear lipid droplets which presumably play a key role in the formation of the nucleoplasmic reticulum and nuclear lipid metabolism [116]. Using human biopsy materials and an obese mouse model, Carracedo and Pandolfi et al. found that hepatic PML protein levels are increased in obese subjects which strongly correlated with liver steatosis, suggesting a role for PML in hepatic function in response to obese conditions [117]. Indeed, an earlier study by Cheng and Kao demonstrated that the depletion of $\mathrm{Pml}$ in mice decreases liver fatty acid accumulation after long-term Western diet feeding and in turn protects mouse liver from dysplastic nodules [118]. Dysplastic nodules are histologically visible benign lesions which follow liver steatosis and are viewed as an early stage of cirrhosis and hepatocellular carcinoma (HCC). It is still unknown how PML contributes to this process while in 50\% HCC patients, PML protein levels are elevated compared to non-neoplastic liver tissue [119]. Since PML controls FAO in stem cells, it is possible that PML participates in the liver disorder by interfering the liver metabolism [114]. Analyses of the microarray data in $P M L$-depleted HUVECs suggest that PML is involved in the regulation of a large cohort of metabolic gene expression $[115,120]$. Along the same line, loss of $P m l$ in mice re-patterns glucose and fatty acid metabolism gene expression in metabolically active tissues, such as muscle and liver, increases metabolic rate and resists obese symptoms induced by a Western diet [118]. It is worthy to note that different results in PML metabolic function and obese predisposition have also been reported [115, 121]. Differences in mouse strains, diets, aging and microbial environment may contribute to the inconsistent phenotypes [115, 118, 121]. Also, since PML participates in brain function, the changes in behavior and appetite after $P m l$ depletion likely contributes to eating disorders and final experimental outcomes [118].

Similar to that found in $\mathrm{Pml} \mathrm{KO}$ mouse muscle and liver [118], elevated AMPK phosphorylation was also repeatedly observed in $\mathrm{Pml}^{-/-}$MEFs, which in turn promotes sustained autophagy through the AMPK-mTOR-Ulk1 pathway [9]. Autophagy is a cell survival mechanism that initiates membrane bound autophagosome formation, facilitates cytosolic protein recycling and saves energy usage under stressful conditions. By this means, Pml knockout MEFs are able to survive under condition of nutrient deprivation but are more sensitive than the wildtype cells to autophagy inhibition [9]. Thus, PML can function as a nutrient sensor that maintains metabolic homeostasis.

In addition to regulation of cytoplasmic protein catabolism via autophagy, PML also controls nuclear protein degradation through the SUMO-Ubiquitin ligation system. In a recent study, Guo et al. found that PML preferentially targets misfolded nuclear proteins and functions as a bona fide SUMO E3 ligase to promote SUMO2/3dependent poly-sumoylation [100]. In the absence of $P m l$, the nuclear ubiquitin E3 ligase, RNF4 is unable to ubiquitinate misfolded proteins destined for proteasomal degradation and thus results in the accumulation of misfolded proteins in the nucleus. For examples, PMLmediated degradation plays a key role in the clearance of neurodegeneration-associated polyglutamine (polyQ) mutant proteins, Atxn1 $82 \mathrm{Q}$ and $\mathrm{Htt} 97 \mathrm{QP}$, as well as overexpressed, aggregate-prone TDP-43 in the nucleus [100]. This is further supported by the observation that loss of $P m l$ exacerbates neurodegeneration phenotypes in a mouse model expressing Atxn1 82Q [100].

\section{Anti-viral PML functions}

Viral infection is viewed as a stress condition in mammalian cells. PML NBs are disrupted upon viral infection and PML expression is induced in response to inflammation, suggesting its role in the anti-viral defense system [122]. An earlier study suggested that the nuclear-replicating DNA viruses preferentially target PML NB [123]. Upon herpes simplex virus 1 (HSV-1) infection, the viral regulatory protein, ICP0, colocalizes with $\mathrm{PML}$ and promotes PML degradation and disassembly of PML NBs [123]. Additionally, the expression of the immediateearly protein BZLF1, induced by Epstein-Barr viral infection, competes PML for sumoylation and consequently leads to PML NB disruption [124]. A similar scenario is also recapitulated by the viral IE1 protein during Cytomegalovirus infection $[125,126]$. One major function of PML against viral infection is to sequester viral core components required for viral replication. For example, PML IV has been shown to interact with 3D polymerase of the RNA virus, encephalomyocarditis virus (EMCV) and sequester it to PML NBs, therefore blocking virus propagation [127]. Alternatively, HIV pre-integration complexes induce nuclear PML shuttling to cytoplasm, in which PML sequesters the HIV genome and blocks the viral transduction in the early infection stage [128]. Most 
importantly, $\mathrm{Pml}^{-1-}$ MEFs are more sensitive to rabies viral infection and $P m l \mathrm{KO}$ mice are susceptible to lymphocytic choriomeningitis and vesicular stomatitis viral infection [129]. In addition to viral infection-induced acute responses, the infection of hepatitis virus and papillomavirus also results in liver and cervical cancers [130]. Since PML has dual function in the defense of viral infection and tumor suppression, it has been proposed that PML participates in the virus-induced tumorigenesis. Taking hepatitis $\mathrm{C}$ virus $(\mathrm{HCV})$ viral infection for example, $\mathrm{HCV}$ core protein can inhibit p53 tumor suppression function by targeting PML [131]. HCV transgenic mice are susceptible to liver tumor under $P m l$ null background, further supporting an idea that PML blocks HCV-mediated tumorigenesis [132]. Although most studies demonstrated PML's function against viruses, other reports suggested that nuclear PML may contribute to viral proliferation in some cases [133].

\section{PML function during the inflammatory response}

In addition to its role in anti-bacteria or -viral infection, PML also participates in innate and adaptive immunity. The detrimental granulomatous lesion, botryomycosis, has been observed when bacterial infection occurred in $\mathrm{Pml}^{-1-}$ mice due to impaired macrophage function [134], suggesting that PML is a regulator of inmate immunity. Indeed, when challenged by bacterial LPS, $\mathrm{Pml}^{-/-}$mice showed reduced septic shock and acute hepatitis, partially due to a decreased response to TLRmediated NFkB survival signaling. Moreover, bacterially infected $\mathrm{Pml}^{-1-}$ MEFs are incapable of producing IL6, a key cytokine critical for the acute inflammatory response [134]. Similarly, IL-1 $\beta$ production is largely reduced in $\mathrm{Pml}^{-1-}$ macrophage due to impaired NLRP3 inflammasome assembly, a key step in the process of IL-1 $\beta$ maturation [135]. The activation of the NLRP3 inflammasome requires PML and is presumably induced by cytoplasmic PML [135]. At the onset of an acute inflammation episode in response to viral infection, TNF and IFN are two early cytokines released into the microenvironment. Interestingly, both cytokines are key PML inducers [29$31,109]$. Reciprocally, PML is required for IFN-mediated anti-viral activity that includes activation of Stats, induction of Stat-associated interferon-stimulated genes (ISGs) and promotion of IFN-induced cell apoptosis [110, 127, 136, 137]. Knockdown of $P M L$ reduces Stat1 function in activating target gene expression by interfering with Stat1 phosphorylation and DNA binding [137]. Knockout or knockdown of $P M L$ does not affect IFNa-induced transient Stat1 phosphorylation or nuclear translocation; however, IFN $\alpha$-induced Stat1 and Stat2 isgylation are reduced [110]. This observation is accompanied by reduced expression of a subset of Stat1-activated genes.
This implies a role for PML in the regulation of Stat1 function [110]. Previous studies suggested that the regulation of Stat 1 by PML mainly resulted from nuclear PML [137], however, whether nuclear or cytoplasmic PML regulates Stat1-isgylation remains unclear and warrants further investigation [137]. In addition, in response to IFN- $\gamma$ stimuli, PML associates with and protects the major histocompatibility complex class II (MHCII) transactivator (CTIIA) from degradation, thus facilitating MHC II gene transcription [138]. Notably, PML also promotes IFN $\beta$ synthesis by enhancing IRF3-induced IFN $\beta$ expression. To do so, PML IV sequesters Pin1 and thereby blocks Pin1-mediated IRF3 ubiquitination and degradation [139]. A recent study further elucidated the connection between viral infection and PML-mediated IFN stimulated gene regulation. Upon Human Cytomegalovirus (HCMV) infection, the HCMV IE1 protein associates with PML and inhibits PML-bound Stat1 and Stat2 activity, resulting in low ISG expression and reduced innate immunity [140]. IFN $\alpha$ has been clinically used for liver cancer therapy due to its anti-angiogenic and pro-apoptotic function. This may rely on PML-mediated apoptotic gene activation. Indeed, PML has been shown to elevate IFN-induced apoptosis by up-regulating the Death receptor, TRAIL [141].

In addition to IFN-mediated responses, knockdown of $P M L$ in TNF $\alpha$ treated HUVECs alters the expression of a large cohort of apoptotic, inflammatory and angiogenic genes [120]. This result suggests a role for PML in TNFmediated responses. Indeed, PML is induced by TNF $\alpha$ at both the transcription and translation levels $[37,109]$. However, how PML works in TNF $\alpha$-mediated inflammatory response is not completely understood. TNF $\alpha$ was first identified as a tumor cytotoxic agent that promotes cancer cell apoptosis [142]. PML is also involved in p53- and Daxx-dependent apoptosis in response to $\gamma$-irradiation, IFN, Fas and TNF $\alpha$ [5, 11, 32, 97, 143]. Several mechanisms have been proposed to elucidate how PML contributes to TNF $\alpha$-induced cell death. It was first shown that ectopic expression of PML converts cancer cells from TNF-resistant to TNF $\alpha$-sensitive cell death, in part by sequestering the pro-survival factor NF $\kappa B$ to PML NBs. This is consistent with the observation that expression of cell survival genes, including TNFAIP3 (A20) and BIRC5 (survivin) was reduced [143, 144]. Secondly, the FAS-interacting protein, Daxx, interacts with PML. It has been proposed that TNF $\alpha$ /FAS ligand-induced PML NBs suppress Daxx anti-apoptotic target gene expression and promote Daxx's function in DSIC-mediated apoptosis $[11,106]$. Because Daxx binds sumoylated PML, this PML function also requires SUMO modification of Daxx [61]. Finally, PML interacts with and regulates other apoptosis-associated transcriptional co-regulators, 
including HDACs. Through this mechanism, PML NBs induced by TNF $\alpha$ may contribute to TNF $\alpha$-mediated inflammatory responses and apoptosis; however, this conclusion requires further investigation [37, 45, 84].

PML function in neurogenesis and brain cognition function The histological distribution of Pml protein in mouse brain, including cerebellum, cortex, hippocampus and the brain stem, suggests that Pml may function in regulating neural development and activity [12, 145, 146]. Indeed, Regad et al. first demonstrated that Pml is expressed in neural progenitor cells (NPCs) in the ventricular zone and controls their proliferation [94]. PML recruits the tumor suppressor protein $\mathrm{RB}$ and phosphatase $\mathrm{PP} 1 \alpha$ in NPC nuclei, resulting in RB hypo-phosphorylation and high activity. Depletion of Pml increases RB phosphorylation and inactivation, consequently promoting NPC proliferation. It also disturbs NPC differentiation and the development of neocortex, and consequently causes a small-size brain phenotype [94]. In addition, multiple neuronal activity regulators, such as PER2 and ARC have been demonstrated to be associated with PML in mature neurons. PML physically interacts with PER2 and this is required for PER2 nuclear localization and PER2-mediated circadian clock gene regulation [76]. In Pml knockout mice, the expression of key circadian regulators, such as PER1 and PER2 is reduced in the suprachiasmatic nucleus and the interaction of PML-PER2 is disrupted, leading to irregular circadian rhythms [76]. Also, Pml knockout mice have fewer whiskers than the wild-type animals, suggesting that these mice are more active [118].

The activity-regulated cytoskeletal protein (Arc) is indispensable for neuronal synaptic plasticity including long-term potentiation (LTP), long-term depression (LTD) and homeostatic scaling [147]. Upon synaptic stimulation, Arc is highly enriched in neuronal nuclei, where it promotes PML NB formation and PML-mediated repression of the activity-regulatory gene, GluA1 [147]. As a result, the Arc-PML-GluA1 axis helps maintain homeostatic of synapse plasticity [147]. In agreement with basic molecular findings, the Pml knockout mice showed lower anxiety-related responses and impaired cognitive function as measured by Morris water maze tests and several other behavior assessments [146]. PML was reported to clear the CNS of toxic protein aggregates in neurodegenerative disease models. The polyQ-containing spinocerebellar ataxia 7 and ataxin 1 are toxic proteins to the CNS which result from abnormal expansion of a polyQ tract in their polypeptide chains [100]. These aggregated proteins colocalize with PML NBs and are degraded in a PML- and proteasomedependent manner [148]. As described earlier, PML catalyzes sumoylation of misfolded proteins and promotes poly-ubiquitination-mediated and proteasome-dependent protein degradation [100]. Based on these findings and the $P m l^{-1-}$ mouse model, the function of PML in CNS regulation is well documented; however, a timely and tissue-specific control of Pml knockout is key to a full understanding of PML function in neuronal development and mature neuron function. Whether targeting PML is a good therapeutic strategy for the treatment of neurodegenerative diseases awaits for further evaluation.

\section{PML function in mammary gland development}

Lessons from PML studies on hematopoietic stem cell and neuron progenitor maintenance highlights PML's function in developmental biology [94, 114]. An analogy has been applied to murine mammary gland development since $P m l$ knockout results in a reduction of murine ductal lumen size and mammary gland branches [34]. Li et al. found that the Pml expression peaks in virgin mammary tissues but decreases during lactation [34]. The Pml expression pattern is negatively correlated with the activities of Stat3, Stat5 and Stat6 [34]. Of these Stats, Stat5 has been reported to regulate differentiation of alveolar cells and Stat6 is required for alveolar lineage expansion [149]. In contrast, Stat 3 promotes cell death to terminate alveolar development at the end of lactation [150]. The inverse activation pattern of Stat5, Stat6 and Stat3 with $P m l$ expression suggested that Stats may transcriptionally suppress Pml expression [34]. This is supported by the observation that $P m l$ expression is increased in either Stat3 or Stat6 knockout mammary gland [34]. Reciprocally, Pml depletion attenuates Stat5 and Stat6 activation, indicating an interplay between PML and Stats in the ductal maturation process [149]. Along with stem cell maintenance in hematopoietic and brain systems, loss of Pml in mice enhances ERa-positive progenitor cloning efficiency, which may lead to the mammary progenitor repopulation and consequent defects in mammary gland maturation [34]. These observations suggest that PML regulates mammary gland morphogenesis and ductal maturation. Also, PML has been proposed to contribute to the tumorigenesis of triple negative and basal-like breast cancers which resemble breast stem/ progenitor cells $[115,151]$. It will be interesting to investigate whether breast cancer stem cells and mammary progenitors share mutual features.

\section{PML function in angiogenesis}

In tissue microarrays, PML has been found highly expressed in endothelium, suggesting that it may play a role in angiogenesis and vascular biology [12]. In response to hypoxia, a low oxygen condition frequently shown in cardiovascular lesions and tumor microenvironments, it was found that $\mathrm{Pml}^{-1-}$ mice showed 
elevated neovascularization [152]. In the tumor microenvironment, the angiogenic system is hijacked by cancer cells and is central for the promotion of tumor growth and metastasis. Under hypoxic conditions, overexpression of PML suppresses mTOR function by sequestering mTOR in the nucleus thereby blocking mTOR-mediated HIF1 protein expression and angiogenesis [152]. Reciprocally, hypoxia-induced HIF1 $\alpha$ upregulated Cul3-KLHL20 ubiquitin ligase which promotes PML ubiquitination and degradation after CDK1/2-mediated PML phosphorylation and subsequent isomerization by Pin1 [58]. As such, prostate cancer cells increase tumor-associated angiogenesis for tumor growth. Along this line, members of the protein serine/threonine phosphatase (SCP) family, dephosphorylate PML and thereby block the CDK1/2Pin1-KLHL20-PML regulatory loop [153]. The frequent deregulation of SCP1 and SCP3 in clear cell renal cell carcinoma and concomitant PML reduction results in mTOR-HIF1 axis activation, thus increasing tumorassociated angiogenesis and tumor burden in Xenograft models [153]. Alternatively, neuroblastoma contain low level of PML I and PML I-induced expression of thrombospondin-2 (TSP2), a potent angiogenic inhibitor [154]. Overexpression of PML I in aggressive neuroblastoma cancer cell lines restored inhibition of tumor-associated angiogenesis [154]. In addition to an intrinsic reduction of PML in cancer cells, it was shown that colorectal cancer cells are capable of reducing PML protein abundance in endothelial cells. Colon cancer cells release microvesicle-capsulated miR-1246 to the recipient endothelial cells and downregulate $P M L$ expression and protein abundance by targeting 3'-UTR of PML I $m R N A$, thus promoting endothelial cell migration and tube formation [35].

Additionally, a transcriptome analysis using $P M L$ knockdown HUVEC implied that PML controls a subset of genes participating in the angiogenic process, including genes that affect cell morphological change, migration and adhesion [36, 37, 109, 110]. Among these PML targeting genes, ITGB1 mRNA and protein levels are upregulated in PML knockdown HUVECs and MDA-231 breast cancer cells $[108,109]$. Thus, upregulation of PML represses ITGB1 expression and inhibits HUVEC and MDA-231 cell migration [108, 155]. Utilizing a similar mechanism, anti-angiogenic cytokines, TNF $\alpha$ and IFN $\alpha$ suppress ITGB1 expression by transcriptionally promoting Stat1-mediated PML expression and thus block EC migration and vascular network formation [109]. Moreover, TNF $\alpha$ activates IRES-driven $P M L$ mRNA translation and PML-dependent anti-angiogenesis via its downstream kinases p38-MNK1 [37]. The induction of PML by TNFo results in HDAC7 sequestration in PML NBs and relieves HDAC7-mediated repression of the vessel destructive factor and matrix proteinase, MMP-10 [84].
Like TNF $\alpha$-mediated anti-angiogenesis, PML up-regulation by IFN $\alpha$ reinforces IFN $\alpha$ downstream angiogenic and angiostatic regulatory loops toward being anti-angiogenic. Mechanistically, PML promotes isgylation and activation of nuclear angiostatic transcription factors, Stat1 and Stat2, but antagonizes angiogenic transcription factor, Stat3, through proteasomal-mediated Stat3 degradation [110]. Manipulation of the isgylation system or ablation of PML tips the PML-Stats regulatory loop and alters this IFN $\alpha$-PML-mediated inhibition of angiogenesis in vitro and ex vivo [110]. Despite the isgylation of Stat1/2 presumably attributed to Stat $1 / 2$-mediated anti-angiogenesis, how ISG15 conjugation affects Stat $1 / 2$ activity in angiogenic gene expression is still unknown. It has been proposed that isgylation of Stat $1 / 2$ regulates their stabilities as in the case for p53 and UBC13 [156, 157]. Further studies on identification of isgylated residues and isgylation-defective mutants should provide information on the functional significance of PML-regulated Stat1/Stat2 isgylation. Altogether, PML functions as a negative regulator in angiogenesis. Manipulation of PML is a key mechanism to regulate tumor-associated angiogenesis and IFN and TNF-mediated angiogenic suppression.

\section{Concluding and remarks}

The main functions of PML are summarized in Fig. 3 and Table 3. The complexity of PML isoforms makes it difficult to clarify and track the precise contribution of each isoform in these processes. Using the CRISPR-knockout technique, experiments with ectopically expressed individual isoforms in a $P M L$ null background are feasible and could provide insights into the function of individual PML isoform. To date, nuclear PML-mediated tumor suppression function is well-documented both in vivo in mouse models and in many types of human cancer $[5,12,25]$. The cytosolic PML also likely functions as a tumor suppressor by controlling calcium transfer and autophagy while the detailed mechanisms require further investigation $[8,9]$. Interestingly, several recent findings highlighted a role of PML in physiologic and pathologic metabolism, especially in FAO and energy usage control $[114,115,117,118]$. Although this mechanism is required for hematopoietic and cancer stem cell renewal, the changes in body mass and high AMPK activation in metabolic tissue in $P m l$ knockout mice suggest a broad spectrum of PML-mediated metabolic regulation [9, 118]. Nevertheless, some inconsistent observations from $P m l$ whole knockout mice are prompting us to investigate PML metabolic function in more strictly defined experimental settings $[115,118,121]$. For example, using a single mouse strain capable of conditionally knocking out $P m l$ in metabolic tissues such as liver and muscle and maintaining it under defined conditions will likely clarify 


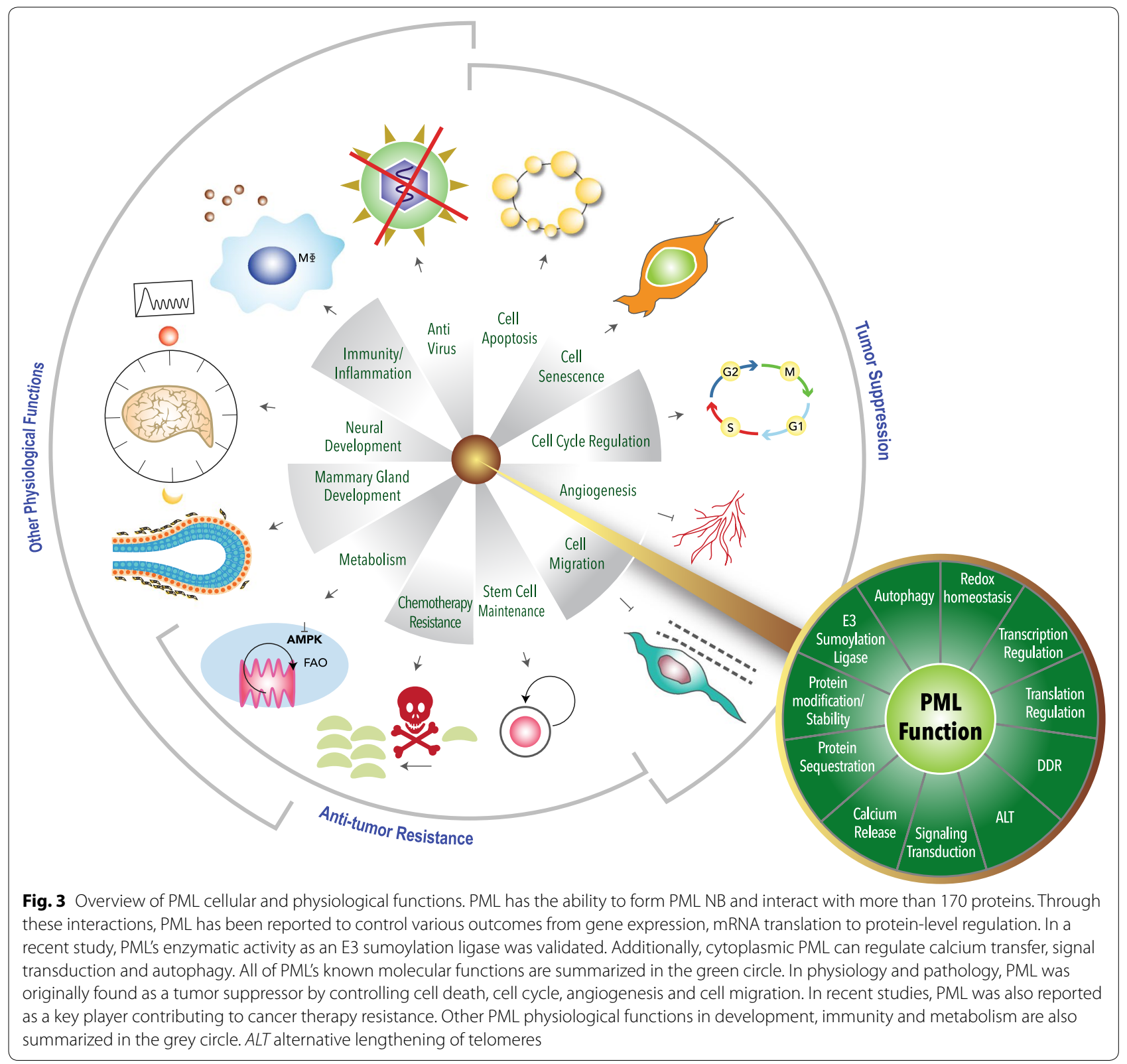

discrepancies currently noted between different studies $[115,118,121]$.

Metabolic disorders such as diabetes and cardiovascular disease are associated with chronic inflammation. Polarization of macrophage is a key step in chronic inflammation. Since PML is a sensor for inflammatory cytokine responses and nutrient status, $\mathrm{Pml}$ knockout macrophage could be employed to investigate whether the deregulation of $P M L$ in macrophage affects inflammation-induced diabetic symptoms [134, 158]. The reduction of PML-mediated angiostatic effects is hijacked by cancer cells to create a tumor favorable microenvironment [35]. Conversely, both anti-tumor cytokines, IFN and TNF, promote PML-mediated angiostatic activity in endothelium [37, 109, 110]. Several clinical investigations and pre-clinical models have suggested that manipulation of PML may be feasible therapeutic strategy for some diseases. For example, the low levels of PML in proliferative diabetic retinopathy implies that up-regulation of PML might mediate angiostatic effects and ameliorate these symptoms in diabetic patients [159]. Additionally, since PML contributes to hematopoietic cancer stem cell self-renewal and the aggressiveness of triple-negative breast cancer, directly reducing PML 


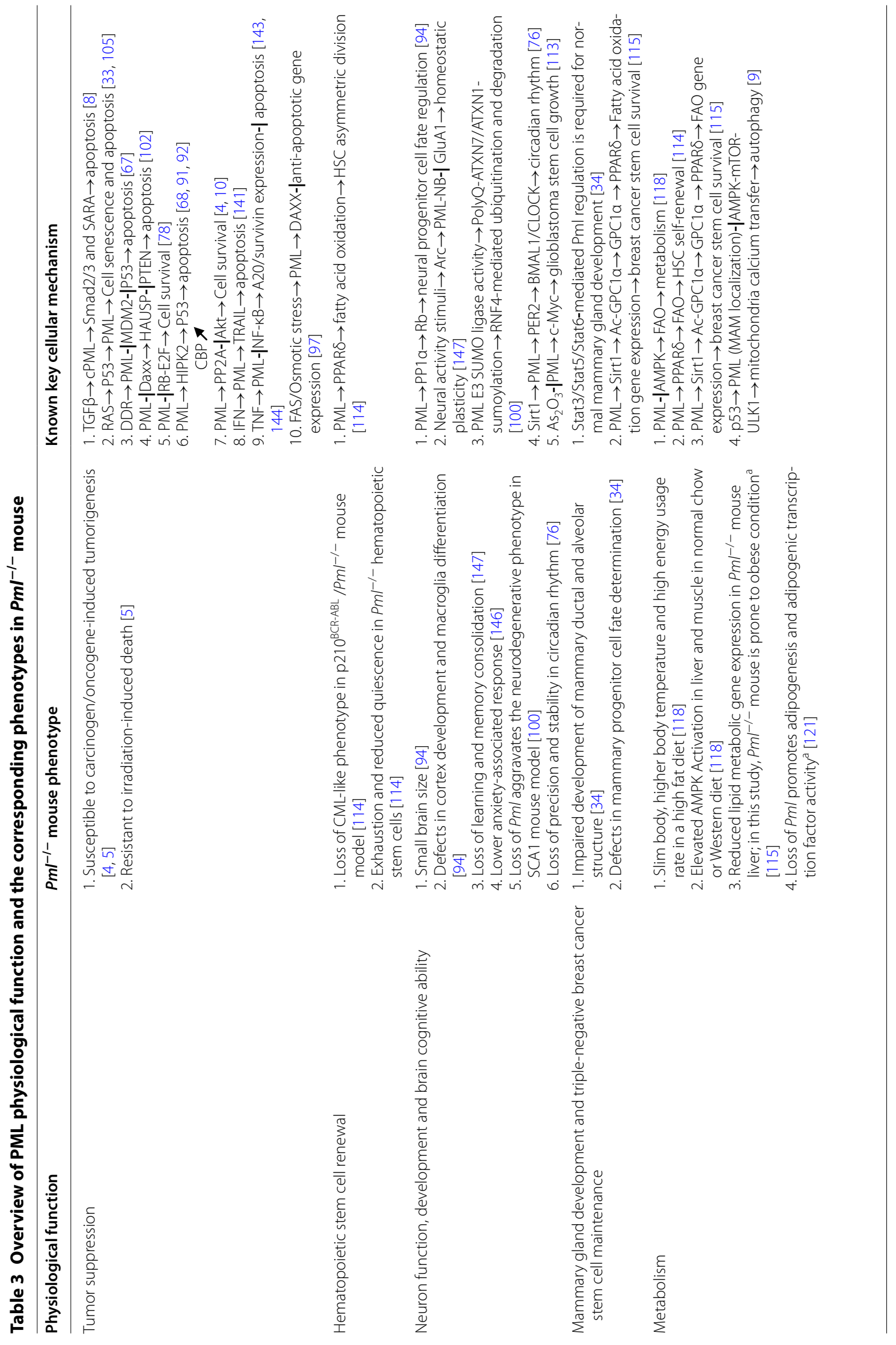




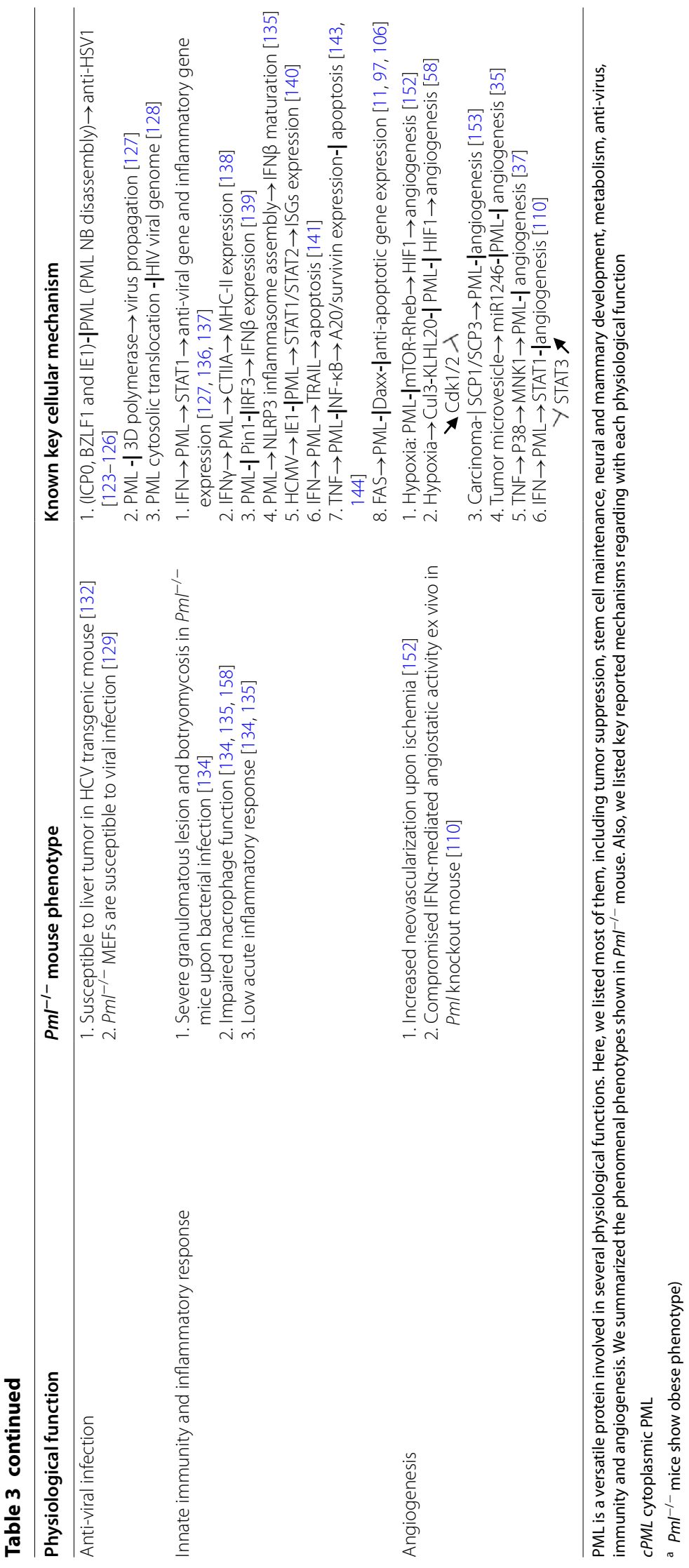


protein levels seems to be a promising strategy to treat some types of cancers. Indeed, results from two recent preclinical studies support this hypothesis. They have treated glioma stem cells and triple-negative breast cancer metastasis with agents promoting PML degradation $[113,151]$. While intensive studies have been focused on post-translational modification and regulation of PML, more exciting findings will be revealed in the years to come. Moreover, few details are known about the underlying mechanisms of transcriptional regulation by PML and translational control of $P M L$ mRNA. New findings on these topics will be important and are highly anticipated. It is also worth noting that a combinational therapy of PML modulating agents with other genotoxic agents has demonstrated a better outcome and provide an effective treatment for a clinical application $[113,151]$. Therefore, the clarification of PML function in these treatments is key to developing more effective therapies in the future.

\footnotetext{
Abbreviations

3KR: PML mutated in K65, K160, and K490; AKT: protein kinase B; AMPK: 5' adenosine monophosphate-activated protein kinase; APL: acute promyelocytic leukemia; ARC: activity-regulated cytoskeleton-associated protein; $\mathrm{As}_{2} \mathrm{O}_{3}$. arsenic trioxide; ATM: the protein kinase ataxia-telangiectasia mutated; ATR: ataxia telangiectasia Rad-3 related kinase; Atxn 1: spinocerebellar ataxia Type 1 protein; BZLF: Epstein-Barr virus replication activator known as Zta; CBP: CREB-binding protein; CDK: cyclin dependent kinase; ChIP: chromatin immunoprecipitation; Chk2: checkpoint kinase 2; CK2: casein kinase 2; CML: chronic myelogenous leukemia; CNS: central nerve system; CTIIA: major histocompatibility complex class II transactivator; Daxx: death-associated protein 6; DDR: DNA damage repair; DNAPK: DNA-dependent protein kinase; elF4E: eukaryotic translation initiation factor $4 \mathrm{E}$; eEF1A1: elongation factor 1A1; EMCV: encephaIomyocarditis virus; ER: endoplasmic reticulum; ERa: estrogen receptor a; FAO: fatty acid oxidation; FAS: apoptosis-mediating surface antigen; GAS: gammaactivated sites; GLUA1: glutamate ionotropic receptor AMPA type subunit 1; H2O2: hydrogen peroxide; HAUSP: ubiquitin-specific-processing protease 7; HCC: hepatocellular carcinoma; HCV: hepatitis C virus; HDAC: histone deacetylase; HIF1: hypoxia-inducible factor 1 ; HIPK2: homeodomain interacting protein kinase 2; HP1: heterochromatin protein 1; HSV-1: herpes simplex virus type 1; Httex1: huntingtin protein; HUVEC: human umbilical vein endothelial cell; ICPO: Human Herpes Virus (HHV) Infected Cell Polypeptide 0; IE1: immediate-early protein 1; IFN: interferon; IP3R: inositol triphosphate receptor; IRES: internal ribosome entry site; IRF: interferon regulatory factor; ISG: interferon-stimulated gene; ISRE: interferon-sensitive response element; ITGB1: integrin $\beta 1$; KLHL: Kelch-like protein; KO: knockout; Kr: Kremer bodies; LPS: lipopolysaccharide; LTD: long-term depression; LTP: long-term potentiation; MAMs: mitochondria-associated membranes; MDM: mouse double minute 2 homolog; MEF: mouse embryonic fibroblast; MHCIl: major histocompatibility complex class II; MMP-10: matrix metallopeptidase 10; MNK: mitogenactivated protein kinase interacting protein kinases; mTOR: mechanistic target of rapamycin; Myc: Myelocytomatosis Viral Oncogene Homolog; NBs: nuclear bodies; NES: nuclear export sequence; NF-kB: nuclear factor kappa-light-chainenhancer of activated B cells; NLRP3: NLR family pyrin domain containing 3; NLS: nuclear localization sequence; NPCs: neural progenitor cells; Nrf2: nuclear factor (erythroid-derived 2)-like 2; PER2: circadian clock protein PERIOD 2; PGC: proliferator-activated receptor gamma coactivator; PIAS1: protein inhibitor of activated STAT 1; PIN1: peptidylprolyl cis/trans isomerase; PolyQ: polyglutamine; PML: promyelocytic leukemia protein; PP2A: protein phosphatase 2A; PPAR: peroxisome proliferator-activated receptor; PTEN: phosphatase and tensin homolog; RA: retinoic acid; RanBP2: RAN binding protein 2; RARa: retinoic acid receptor alpha; RAS: Rat Sarcoma Viral Oncogene Homolog; RB: retinoblastoma protein; $\mathrm{RBCC}$ : ring finger/B box/coiled-coil; RNF: ring finger
}

proteins; ROS: reactive oxygen species; SARA: SMAD anchor for receptor activation; SCA1: spinocerebellar ataxia type 1 gene; SCP: small CTD (carboxyterminal domain, RNA polymerase II, polypeptide A) phosphatase; Sdhaf: succinate dehydrogenase complex assembly factor; SENP: SUMO-specific protease; SIAH: seven in absentia homolog; SIM: SUMO-interacting motif; Sirt1: sirtuin 1; Smad: protein similar to mothers against decapentaplegic; STAT: signal transducers and activators of transcription; SUMO: small ubiquitin-like modifier; TGF: transforming growth factor; TLR: toll-like receptor;TNF: tumor necrosis factor; TOPORS: TOP1 binding arginine/serine rich protein; TRAIL:TNFrelated apoptosis inducing ligand; TRIM: tripartite motif; TSP2: thrombospondin-2; Ub: ubiquitin; UBC13: ubiquitin-conjugating enzyme13; UBE1: ubiquitin activating enzyme E1; USP: ubiquitin specific peptidase; UTR: untranslated region; ZNF: zinc finger.

\section{Authors' contributions}

$\mathrm{KSH}$ and HYK contributed to manuscript writing. Both authors read and approved the final manuscript.

\section{Author details}

${ }^{1}$ Department of Biochemistry, Case Western Reserve University, 10900 Euclid Avenue, Cleveland, OH 44106, USA. ${ }^{2}$ The Comprehensive Cancer Center of Case Western Reserve University and University Hospitals of Cleveland, Cleveland, OH 44106, USA. ${ }^{3}$ Present Address: Tumor Angiogenesis Section, Mouse Cancer Genetics Program (MCGP), National Cancer Institute (NCI), NIH, Frederick, MD 21702, USA.

\section{Competing interests}

The authors declare that they have no competing interests.

\section{Availability of data and materials}

All data are available without restrictions.

\section{Consent for publication}

All authors consented for publication.

\section{Ethics approval and consent to participate}

The review article has no relevant ethical issue for approval and consent to participate.

\section{Funding}

Not applicable.

\section{Publisher's Note}

Springer Nature remains neutral with regard to jurisdictional claims in published maps and institutional affiliations.

Received: 10 December 2017 Accepted: 12 January 2018

Published online: 25 January 2018

\section{References}

1. de The H, Chomienne C, Lanotte M, Degos L, Dejean A. The $t(15 ; 17)$ translocation of acute promyelocytic leukaemia fuses the retinoic acid receptor alpha gene to a novel transcribed locus. Nature. 1990;347:558-61.

2. Goddard A, Borrow J, Freemont P, Solomon E. Characterization of a zinc finger gene disrupted by the $t(15 ; 17)$ in acute promyelocytic leukemia. Science. 1991;254:1371-4

3. Kakizuka A, Miller WH Jr, Umesono K, Warrell RP Jr, Frankel SR, Murty WVS, Dmitrovsky E, Evans RM. Chromosomal translocation t(15;17) in human acute promyelocytic leukemia fuses RARa with a novel putative transcription factor. PML Cell. 1991;66:663-74.

4. Trotman LC, Alimonti A, Scaglioni PP, Koutcher JA, Cordon-Cardo C, Pandolfi PP. Identification of a tumour suppressor network opposing nuclear Akt function. Nature. 2006;441:523-7.

5. Wang ZG, Ruggero D, Ronchetti S, Zhong S, Gaboli M, Rivi R, Pandolfi PP. PML is essential for multiple apoptotic pathways. Nat Genet. 1998;20:266-72. 
6. Dellaire G, Bazett-Jones DP. PML nuclear bodies: dynamic sensors of DNA damage and cellular stress. BioEssays. 2004;26:963-77.

7. Lallemand-Breitenbach V, de Thé H. PML nuclear bodies. Cold Spring Harb Perspect Biol. 2010;2:a000661.

8. Lin HK, Bergmann S, Pandolfi PP. Cytoplasmic PML function in TGF-beta signalling. Nature. 2004;431:205-11.

9. Missiroli S, Bonora M, Patergnani S, Poletti F, Perrone M, Gafa R, Magri E, Raimondi A, Lanza G, Tacchetti C, et al. PML at mitochondria-associated membranes is critical for the repression of autophagy and cancer development. Cell Rep. 2016;16:2415-27.

10. Giorgi C, Ito K, Lin HK, Santangelo C, Wieckowski MR, Lebiedzinska M, Bononi A, Bonora M, Duszynski J, Bernardi R, et al. PML regulates apoptosis at endoplasmic reticulum by modulating calcium release. Science. 2010;330:1247-51.

11. Bernardi R, Pandolfi PP. Role of PML and the PML-nuclear body in the control of programmed cell death. Oncogene. 2003;22:9048-57.

12. Gurrieri C, Capodieci P, Bernardi R, Scaglioni PP, Nafa K, Rush LJ, Verbel DA, Cordon-Cardo C, Pandolfi PP. Loss of the tumor suppressor PML in human cancers of multiple histologic origins. J Natl Cancer Inst. 2004;96:269-79.

13. Bernardi R, Pandolfi PP. Structure, dynamics and functions of promyelocytic leukaemia nuclear bodies. Nat Rev Mol Cell Biol. 2007;8:1006-16.

14. Borden KL. Pondering the promyelocytic leukemia protein (PML) puzzle: possible functions for PML nuclear bodies. Mol Cell Biol. 2002;22:5259-69.

15. Cheng $X$, Kao HY. Post-translational modifications of PML: consequences and implications. Front Oncol. 2012;2:210.

16. Jensen K, Shiels C, Freemont PS. PML protein isoforms and the RBCC/ TRIM motif. Oncogene. 2001;20:7223-33.

17. Borden KL, Boddy MN, Lally J, O'Reilly NJ, Martin S, Howe K, Solomon E, Freemont PS. The solution structure of the RING finger domain from the acute promyelocytic leukaemia proto-oncoprotein PML. EMBO J. 1995;14:1532-41.

18. Fagioli M, Alcalay M, Tomassoni L, Ferrucci PF, Mencarelli A, Riganelli D, Grignani F, Pozzan T, Nicoletti I, Grignani F, Pelicci PG. Cooperation between the RING + B1-B2 and coiled-coil domains of PML is necessary for its effects on cell survival. Oncogene. 1998;16:2905-13.

19. Nisole S, Maroui MA, Mascle XH, Aubry M, Chelbi-Alix MK. Differential roles of PML isoforms. Front Oncol. 2013;3:125.

20. Shen TH, Lin HK, Scaglioni PP, Yung TM, Pandolf PP. The mechanisms of PML-nuclear body formation. Mol Cell. 2006;24:331-9.

21. Boisvert FM, Hendzel MJ, Bazett-Jones DP. Promyelocytic leukemia (PML) nuclear bodies are protein structures that do not accumulate RNA. J Cell Biol. 2000;148:283-92.

22. Van Damme E, Laukens K, Dang TH, Van Ostade X. A manually curated network of the PML nuclear body interactome reveals an important role for PML-NBs in SUMOylation dynamics. Int J Biol Sci. 2010;6:51-67.

23. Zhu J, Lallemand-Breitenbach V, de The H. Pathways of retinoic acid- or arsenic trioxide-induced PML/RARalpha catabolism, role of oncogene degradation in disease remission. Oncogene. 2001;20:7257-65.

24. Sahin U, Ferhi O, Jeanne M, Benhenda S, Berthier C, Jollivet F, NiwaKawakita M, Faklaris O, Setterblad N, de The H, Lallemand-Breitenbach V. Oxidative stress-induced assembly of PML nuclear bodies controls sumoylation of partner proteins. J Cell Biol. 2014;204:931-45.

25. Carracedo A, Ito K, Pandolfi PP. The nuclear bodies inside out: PML conquers the cytoplasm. Curr Opin Cell Biol. 2011;23:360-6.

26. Bellodi C, Kindle K, Bernassola F, Cossarizza A, Dinsdale D, Melino G, Heery D, Salomoni P. A cytoplasmic PML mutant inhibits p53 function. Cell Cycle. 2006;5:2688-92.

27. McNally BA, Trgovcich J, Maul GG, Liu Y, Zheng P. A role for cytoplasmic PML in cellular resistance to viral infection. PLOS ONE. 2008;3:e2277.

28. Guo S, Cheng X, Lim JH, Liu Y, Kao HY. Control of antioxidative response by the tumor suppressor protein PML through regulating Nrf2 activity. Mol Biol Cell. 2014;25:2485-98.

29. Chelbi-Alix MK, Pelicano L, Quignon F, Koken MH, Venturini L, Stadler M, Pavlovic J, Degos L, de The H. Induction of the PML protein by interferons in normal and APL cells. Leukemia. 1995;9:2027-33.

30. Stadler M, Chelbi-Alix MK, Koken MH, Venturini L, Lee C, Saib A, Quignon F, Pelicano L, Guillemin MC, Schindler C, et al. Transcriptional induction of the PML growth suppressor gene by interferons is mediated through an ISRE and a GAS element. Oncogene. 1995;11:2565-73.
31. Dror N, Rave-Harel N, Burchert A, Azriel A, Tamura T, Tailor P, Neubauer A, Ozato K, Levi BZ. Interferon regulatory factor-8 is indispensable for the expression of promyelocytic leukemia and the formation of nuclear bodies in myeloid cells. J Biol Chem. 2007;282:5633-40.

32. de Stanchina E, Querido E, Narita M, Davuluri RV, Pandolfi PP, Ferbeyre G, Lowe SW. PML is a direct p53 target that modulates p53 effector functions. Mol Cell. 2004;13:523-35.

33. Ferbeyre G, de Stanchina E, Querido E, Baptiste N, Prives C, Lowe SW. PML is induced by oncogenic ras and promotes premature senescence. Genes Dev. 2000;14:2015-27.

34. Li W, Ferguson BJ, Khaled WT, Tevendale M, Stingl J, Poli V, Rich T, Salomoni P, Watson CJ. PML depletion disrupts normal mammary gland development and skews the composition of the mammary luminal cell progenitor pool. Proc Natl Acad Sci USA. 2009;106:4725-30.

35. Yamada N, Tsujimura N, Kumazaki M, Shinohara H, Taniguchi K, Nakagawa Y, Naoe T, Akao Y. Colorectal cancer cell-derived microvesicles containing microRNA-1246 promote angiogenesis by activating Smad 1/5/8 signaling elicited by PML down-regulation in endothelial cells. Biochim Biophys Acta. 2014;1839:1256-72.

36. Scaglioni PP, Rabellino A, Yung TM, Bernardi R, Choi S, Konstantinidou G, Nardella C, Cheng K, Pandolfi PP. Translation-dependent mechanisms lead to PML upregulation and mediate oncogenic K-RAS-induced cellular senescence. EMBO Mol Med. 2012;4:594-602.

37. Hsu KS, Guan BJ, Cheng X, Guan D, Lam M, Hatzoglou M, Kao HY. Translational control of PML contributes to TNFalpha-induced apoptosis of MCF7 breast cancer cells and decreased angiogenesis in HUVECs. Cell Death Differ. 2016;23:469-83.

38. Kamitani T, Kito K, Nguyen HP, Wada H, Fukuda-Kamitani T, Yeh ET. Identification of three major sentrinization sites in PML. J Biol Chem. 1998;273:26675-82.

39. Liang YC, Lee CC, Yao YL, Lai CC, Schmitz ML, Yang WM. SUMO5, a novel poly-SUMO isoform. Regulates PML Nuclear Bodies. Sci Rep. 2016;6:26509.

40. Matunis MJ, Zhang XD, Ellis NA. SUMO: the glue that binds. Dev Cell. 2006;11:596-7.

41. Koidl S, Eisenhardt N, Fatouros C, Droescher M, Chaugule VK, Pichler A. The SUMO2/3 specific E3 ligase ZNF451-1 regulates PML stability. Int J Biochem Cell Biol. 2016;79:478-87.

42. Tatham MH, Kim S, Jaffray E, Song J, Chen Y, Hay RT. Unique binding interactions among Ubc9, SUMO and RanBP2 reveal a mechanism for SUMO paralog selection. Nat Struct Mol Biol. 2005;12:67-74.

43. Saitoh N, Uchimura Y, Tachibana T, Sugahara S, Saitoh H, Nakao M. In situ SUMOylation analysis reveals a modulatory role of RanBP2 in the nuclear rim and PML bodies. Exp Cell Res. 2006;312:1418-30.

44. Rabellino A, Carter B, Konstantinidou G, Wu SY, Rimessi A, Byers LA, Heymach JV, Girard L, Chiang CM, Teruya-Feldstein J, Scaglioni PP. The SUMO E3-ligase PIAS1 regulates the tumor suppressor PML and its oncogenic counterpart PML-RARA. Cancer Res. 2012;72:2275-84.

45. Gao C, Ho CC, Reineke E, Lam M, Cheng X, Stanya KJ, Liu Y, Chakraborty S, Shih HM, Kao HY. Histone deacetylase 7 promotes PML sumoylation and is essential for PML nuclear body formation. Mol Cell Biol. 2008;28:5658-67.

46. Gong L, Millas S, Maul GG, Yeh ET. Differential regulation of sentrinized proteins by a novel sentrin-specific protease. J Biol Chem. 2000;275:3355-9.

47. Best JL, Ganiatsas S, Agarwal S, Changou A, Salomoni P, Shirihai O, Meluh PB, Pandolfi PP, Zon LI. SUMO-1 protease-1 regulates gene transcription through PML. Mol Cell. 2002;10:843-55.

48. Han Y, Huang C, Sun X, Xiang B, Wang M, Yeh ET, Chen Y, Li H, Shi G, Cang $\mathrm{H}$, et al. SENP3-mediated de-conjugation of SUMO2/3 from promyelocytic leukemia is correlated with accelerated cell proliferation under mild oxidative stress. J Biol Chem. 2010;285:12906-15.

49. Gong L, Yeh ET. Characterization of a family of nucleolar SUMO-specific proteases with preference for SUMO-2 or SUMO-3. J Biol Chem. 2006;281:15869-77.

50. Mukhopadhyay D, Ayaydin F, Kolli N, Tan SH, Anan T, Kametaka A, Azuma Y, Wilkinson KD, Dasso M. SUSP1 antagonizes formation of highly SUMO2/3-conjugated species. J Cell Biol. 2006;174:939-49.

51. Weisshaar SR, Keusekotten K, Krause A, Horst C, Springer HM, Gottsche K, Dohmen RJ, Praefcke GJ. Arsenic trioxide stimulates SUMO-2/3 
modification leading to RNF4-dependent proteolytic targeting of PML. FEBS Lett. 2008;582:3174-8.

52. Dellaire G, Ching RW, Ahmed K, Jalali F, Tse KC, Bristow RG, Bazett-Jones DP. Promyelocytic leukemia nuclear bodies behave as DNA damage sensors whose response to DNA double-strand breaks is regulated by NBS1 and the kinases ATM, Chk2, and ATR. J Cell Biol. 2006;175:55-66.

53. Jeanne M, Lallemand-Breitenbach V, Ferhi O, Koken M, Le Bras M, Duffort S, Peres L, Berthier C, Soilihi H, Raught B, de The H. PML/RARA oxidation and arsenic binding initiate the antileukemia response of $\mathrm{As} 2 \mathrm{O} 3$. Cancer Cell. 2010;18:88-98.

54. Zhang XW, Yan XJ, Zhou ZR, Yang FF, Wu ZY, Sun HB, Liang WX, Song $A X$, Lallemand-Breitenbach $V$, Jeanne $M$, et al. Arsenic trioxide controls the fate of the PML-RARalpha oncoprotein by directly binding PML. Science. 2010;328:240-3.

55. Louria-Hayon I, Alsheich-Bartok O, Levav-Cohen Y, Silberman I, Berger M, Grossman T, Matentzoglu K, Jiang YH, Muller S, Scheffner M, et al. E6AP promotes the degradation of the PML tumor suppressor. Cell Death Differ. 2009;16:1156-66.

56. Wolyniec K, Shortt J, de Stanchina E, Levav-Cohen Y, Alsheich-Bartok O, Louria-Hayon I, Corneille V, Kumar B, Woods SJ, Opat S, et al. E6AP ubiquitin ligase regulates PML-induced senescence in Myc-driven lymphomagenesis. Blood. 2012;120:822-32.

57. Fanelli M, Fantozzi A, De Luca P, Caprodossi S, Matsuzawa S, Lazar MA, Pelicci PG, Minucci S. The coiled-coil domain is the structural determinant for mammalian homologues of Drosophila Sina-mediated degradation of promyelocytic leukemia protein and other tripartite motif proteins by the proteasome. J Biol Chem. 2004;279:5374-9.

58. Yuan WC, Lee YR, Huang SF, Lin YM, Chen TY, Chung HC, Tsai CH, Chen HY, Chiang CT, Lai CK, et al. A Cullin3-KLHL20 Ubiquitin ligase-dependent pathway targets PML to potentiate HIF-1 signaling and prostate cancer progression. Cancer Cell. 2011;20:214-28.

59. Erker Y, Neyret-Kahn H, Seeler JS, Dejean A, Atfi A, Levy L. Arkadia, a novel SUMO-targeted ubiquitin ligase involved in PML degradation. Mol Cell Biol. 2013;33:2163-77.

60. Geoffroy MC, Jaffray EG, Walker KJ, Hay RT. Arsenic-induced SUMOdependent recruitment of RNF4 into PML nuclear bodies. Mol Biol Cell. 2010;21:4227-39.

61. Lin DY, Huang YS, Jeng JC, Kuo HY, Chang CC, Chao TT, Ho CC, Chen $Y C$, Lin TP, Fang HI, et al. Role of SUMO-interacting motif in Daxx SUMO modification, subnuclear localization, and repression of sumoylated transcription factors. Mol Cell. 2006;24:341-54.

62. Kitareewan S, Pitha-Rowe I, Sekula D, Lowrey CH, Nemeth MJ, Golub TR, Freemantle SJ, Dmitrovsky E. UBE1L is a retinoid target that triggers PML/RARa degradation and apoptosis in acute promyelocytic leukemia. Proc Natl Acad Sci USA. 2002;99:3806-11.

63. Shah SJ, Blumen S, Pitha-Rowe I, Kitareewan S, Freemantle SJ, Feng Q, Dmitrovsky E. UBE1L represses PML/RAR \{alpha\} by targeting the PML domain for ISG15ylation. Mol Cancer Ther. 2008;7:905-14.

64. Guo Y, Dolinko AV, Chinyengetere F, Stanton B, Bomberger JM, Demidenko E, Zhou DC, Gallagher R, Ma T, Galimberti F, et al. Blockade of the ubiquitin protease UBP43 destabilizes transcription factor PML/ RARalpha and inhibits the growth of acute promyelocytic leukemia. Cancer Res. 2010;70:9875-85.

65. Schmitz ML, Grishina I. Regulation of the tumor suppressor PML by sequential post-translational modifications. Front Oncol. 2012;2:204.

66. Yang S, Kuo C, Bisi JE, Kim MK. PML-dependent apoptosis after DNA damage is regulated by the checkpoint kinase hCds1/Chk2. Nat Cell Biol. 2002:4:865-70.

67. Bernardi R, Scaglioni PP, Bergmann S, Horn HF, Vousden KH, Pandolfi PP. PML regulates $p 53$ stability by sequestering $\mathrm{Mdm} 2$ to the nucleolus. Nat Cell Biol. 2004;6:665-72.

68. Gresko E, Ritterhoff S, Sevilla-Perez J, Roscic A, Frobius K, Kotevic I, Vichalkovski A, Hess D, Hemmings BA, Schmitz ML. PML tumor suppressor is regulated by HIPK2-mediated phosphorylation in response to DNA damage. Oncogene. 2009;28:698-708.

69. Hayakawa F, Privalsky ML. Phosphorylation of PML by mitogenactivated protein kinases plays a key role in arsenic trioxide-mediated apoptosis. Cancer Cell. 2004;5:389-401.

70. Lim JH, Liu Y, Reineke E, Kao HY. Mitogen-activated protein kinase extracellular signal-regulated kinase 2 phosphorylates and promotes
Pin1 protein-dependent promyelocytic leukemia protein turnover. J Biol Chem. 2011;286:44403-11.

71. Reineke EL, Lam M, Liu Q, Liu Y, Stanya KJ, Chang KS, Means AR, Kao HY. Degradation of the tumor suppressor PML by Pin 1 contributes to the cancer phenotype of breast cancer MDA-MB-231 cells. Mol Cell Biol. 2008;28:997-1006.

72. Dephoure N, Zhou C, Villen J, Beausoleil SA, Bakalarski CE, Elledge SJ, Gygi SP. A quantitative atlas of mitotic phosphorylation. Proc Natl Acad Sci USA. 2008;105:10762-7.

73. Scaglioni PP, Yung TM, Cai LF, Erdjument-Bromage H, Kaufman AJ, Singh B, Teruya-Feldstein J, Tempst P, Pandolfi PP. A CK2-dependent mechanism for degradation of the PML tumor suppressor. Cell. 2006;126:269-83.

74. Hayakawa F, Abe A, Kitabayashi I, Pandolfi PP, Naoe T. Acetylation of PML is involved in histone deacetylase inhibitor-mediated apoptosis. J Biol Chem. 2008;283:24420-5.

75. Campagna M, Herranz D, Garcia MA, Marcos-Villar L, Gonzalez-Santamaria J, Gallego P, Gutierrez S, Collado M, Serrano M, Esteban M, Rivas C. SIRT1 stabilizes PML promoting its sumoylation. Cell Death Differ. 2011:18:72-9.

76. Miki T, Xu Z, Chen-Goodspeed M, Liu M, Van Oort-Jansen A, Rea MA, Zhao Z, Lee CC, Chang KS. PML regulates PER2 nuclear localization and circadian function. EMBO J. 2012;31:1427-39.

77. Guan D, Lim JH, Peng L, Liu Y, Lam M, Seto E, Kao HY. Deacetylation of the tumor suppressor protein PML regulates hydrogen peroxideinduced cell death. Cell Death Dis. 2014;5:e1340.

78. Vernier M, Bourdeau V, Gaumont-Leclerc MF, Moiseeva O, Begin V, Saad F, Mes-Masson AM, Ferbeyre G. Regulation of E2Fs and senescence by PML nuclear bodies. Genes Dev. 2011;25:41-50.

79. Salsman J, Stathakis A, Parker E, Chung D, Anthes LE, Koskowich KL, Lahsaee S, Gaston D, Kukurba KR, Smith KS, et al. PML nuclear bodies contribute to the basal expression of the mTOR inhibitor DDIT4. Sci Rep. 2017;7:45038

80. Tessier S, Martin-Martin N, de The H, Carracedo A, LallemandBreitenbach V. Promyelocytic leukemia protein, a protein at the crossroad of oxidative stress and metabolism. Antioxid Redox Signal. 2017:26:432-44

81. Khan MM, Nomura T, Kim H, Kaul SC, Wadhwa R, Shinagawa T, IchikawaIwata E, Zhong S, Pandolf PP, Ishii S. Role of PML and PML-RARalpha in mad-mediated transcriptional repression. Mol Cell. 2001;7:1233-43.

82. Lin DY, Lai MZ, Ann DK, Shih HM. Promyelocytic leukemia protein (PML) functions as a glucocorticoid receptor co-activator by sequestering Daxx to the PML oncogenic domains (PODs) to enhance its transactivation potential. J Biol Chem. 2003;278:15958-65.

83. Lehembre F, Muller S, Pandolfi PP, Dejean A. Regulation of Pax3 transcriptional activity by SUMO-1-modified PML. Oncogene. 2001:20:1-9.

84. Gao C, Cheng X, Lam M, Liu Y, Liu Q, Chang KS, Kao HY. Signal-dependent regulation of transcription by histone deacetylase 7 involves recruitment to promyelocytic leukemia protein nuclear bodies. Mol Biol Cell. 2008;19:3020-7.

85. Kumar PP, Bischof O, Purbey PK, Notani D, Urlaub H, Dejean A, Galande S. Functional interaction between PML and SATB1 regulates chromatinloop architecture and transcription of the MHC class I locus. Nat Cell Biol. 2007;9:45-56.

86. Sun Y, Durrin LK, Krontiris TG. Specific interaction of PML bodies with the TP53 locus in Jurkat interphase nuclei. Genomics. 2003;82:250-2.

87. Culjkovic B, Topisirovic I, Skrabanek L, Ruiz-Gutierrez M, Borden KL. elF4E is a central node of an RNA regulon that governs cellular proliferation. J Cell Biol. 2006;175:415-26.

88. Lai HK, Borden KL. The promyelocytic leukemia (PML) protein suppresses cyclin D1 protein production by altering the nuclear cytoplasmic distribution of cyclin D1 mRNA. Oncogene. 2000;19:1623-34.

89. Iborra FJ, Jackson DA, Cook PR. Coupled transcription and translation within nuclei of mammalian cells. Science. 2001;293:1139-42.

90. Strudwick S, Borden KL. The emerging roles of translation factor elF4E in the nucleus. Differentiation. 2002;70:10-22.

91. D'Orazi G, Cecchinelli B, Bruno T, Manni I, Higashimoto Y, Saito S, Gostissa M, Coen S, Marchetti A, Del Sal G, et al. Homeodomain-interacting protein kinase-2 phosphorylates p53 at Ser 46 and mediates apoptosis. Nat Cell Biol. 2002:4:11-9. 
92. Hofmann TG, Moller A, Sirma H, Zentgraf H, Taya Y, Droge W, Will $\mathrm{H}$, Schmitz ML. Regulation of p53 activity by its interaction with homeodomain-interacting protein kinase-2. Nat Cell Biol. 2002;4:1-10.

93. Langley E, Pearson M, Faretta M, Bauer UM, Frye RA, Minucci S, Pelicci PG, Kouzarides T. Human SIR2 deacetylates p53 and antagonizes PML/ p53-induced cellular senescence. EMBO J. 2002;21:2383-96.

94. Regad T, Bellodi C, Nicotera P, Salomoni P. The tumor suppressor $\mathrm{Pml}$ regulates cell fate in the developing neocortex. Nat Neurosci. 2009;12:132-40.

95. Renner F, Moreno R, Schmitz ML. SUMOylation-dependent localization of IKKepsilon in PML nuclear bodies is essential for protection against DNA-damage-triggered cell death. Mol Cell. 2010;37:503-15.

96. Lallemand-Breitenbach V, Zhu J, Puvion F, Koken M, Honore N, Doubeikovsky A, Duprez E, Pandolfi PP, Puvion E, Freemont P, de The H. Role of promyelocytic leukemia (PML) sumolation in nuclear body formation, $11 \mathrm{~S}$ proteasome recruitment, and As2O3-induced PML or PML/retinoic acid receptor alpha degradation. J Exp Med. 2001;193:1361-71.

97. Chang C-C, Naik Mandar T, Huang Y-S, Jeng J-C, Liao P-H, Kuo H-Y, Ho C-C, Hsieh Y-L, Lin C-H, Huang N-J, et al. Structural and functional roles of Daxx SIM phosphorylation in SUMO paralog-selective binding and apoptosis modulation. Mol Cell. 2011;42:62-74.

98. Malloy MT, Mclntosh DJ, Walters TS, Flores A, Goodwin JS, Arinze IJ. Trafficking of the transcription factor Nrf2 to promyelocytic leukemianuclear bodies: implications for degradation of NRF2 in the nucleus. J Biol Chem. 2013;288:14569-83.

99. Chu Y, Yang X. SUMO E3 ligase activity of TRIM proteins. Oncogene. 2011;30:1108-16.

100. Guo L, Giasson BI, Glavis-Bloom A, Brewer MD, Shorter J, Gitler AD, Yang $X$. A cellular system that degrades misfolded proteins and protects against neurodegeneration. Mol Cell. 2014;55:15-30.

101. Lee YR, Yuan WC, Ho HC, Chen $\mathrm{CH}$, Shih HM, Chen RH. The Cullin 3 substrate adaptor KLHL20 mediates DAPK ubiquitination to control interferon responses. EMBO J. 2010;29:1748-61.

102. Song MS, Salmena L, Carracedo A, Egia A, Lo-Coco F, Teruya-Feldstein J, Pandolfi PP. The deubiquitinylation and localization of PTEN are regulated by a HAUSP-PML network. Nature. 2008;455:813-7.

103. Zhang P, Chin W, Chow LT, Chan AS, Yim AP, Leung SF, MokTS, Chang KS, Johnson PJ, Chan JY. Lack of expression for the suppressor PML in human small cell lung carcinoma. Int J Cancer. 2000;85:599-605.

104. Gambacorta M, Flenghi L, Fagioli M, Pileri S, Leoncini L, Bigerna B, Pacini R, Tanci LN, Pasqualucci L, Ascani S, et al. Heterogeneous nuclear expression of the promyelocytic leukemia (PML) protein in normal and neoplastic human tissues. Am J Pathol. 1996;149:2023-35.

105. Pearson M, Carbone R, Sebastiani C, Cioce M, Fagioli M, Saito S, Higashimoto Y, Appella E, Minucci S, Pandolfi PP, Pelicci PG. PML regulates p53 acetylation and premature senescence induced by oncogenic Ras. Nature. 2000;406:207-10.

106. Zhong S, Salomoni P, Pandolfi PP. The transcriptional role of PML and the nuclear body. Nat Cell Biol. 2000;2:E85-90.

107. Oh W, Ghim J, Lee EW, Yang MR, Kim ET, Ahn JH, Song J. PML-IV functions as a negative regulator of telomerase by interacting with TERT. J Cell Sci. 2009;122:2613-22.

108. Reineke EL, Liu Y, Kao HY. Promyelocytic leukemia protein controls cell migration in response to hydrogen peroxide and insulin-like growth factor-1. J Biol Chem. 2010;285:9485-92.

109. Cheng X, Liu Y, Chu H, Kao HY. Promyelocytic leukemia protein (PML) regulates endothelial cell network formation and migration in response to tumor necrosis factor alpha (TNFalpha) and interferon alpha (IFNalpha). J Biol Chem. 2012;287:23356-67.

110. Hsu KS, Zhao X, Cheng X, Guan D, Mahabeleshwar GH, Liu Y, Borden E, Jain MK, Kao HY. Dual regulation of Stat1 and Stat3 by the tumor suppressor protein PML contributes to interferon alpha-mediated inhibition of angiogenesis. J Biol Chem. 2017;292:10048-60.

111. Zhou W, Bao S. PML-mediated signaling and its role in cancer stem cells. Oncogene. 2014;33:1475-84.

112. Iwanami A, Gini B, Zanca C, Matsutani T, Assuncao A, Nael A, Dang J, Yang $\mathrm{H}$, Zhu S, Kohyama J, et al. PML mediates glioblastoma resistance to mammalian target of rapamycin (mTOR)-targeted therapies. Proc Natl Acad Sci USA. 2013;110:4339-44.

113. Zhou W, Cheng L, Shi Y, Ke SQ, Huang Z, Fang X, Chu CW, Xie Q, Bian XW, Rich JN, Bao S. Arsenic trioxide disrupts glioma stem cells via promoting PML degradation to inhibit tumor growth. Oncotarget. 2015;6:37300-15.

114. Ito K, Bernardi R, Morotti A, Matsuoka S, Saglio G, Ikeda Y, Rosenblatt J, Avigan DE, Teruya-Feldstein J, Pandolfi PP. PML targeting eradicates quiescent leukaemia-initiating cells. Nature. 2008;453:1072-8.

115. Carracedo A, Weiss D, Leliaert AK, Bhasin M, de Boer VC, Laurent G, Adams AC, Sundvall M, Song SJ, Ito K, et al. A metabolic prosurvival role for PML in breast cancer. J Clin Invest. 2012;122:3088-100.

116. Ohsaki Y, Kawai T, Yoshikawa Y, Cheng J, Jokitalo E, Fujimoto T. PML isoform II plays a critical role in nuclear lipid droplet formation. J Cell Biol. 2016;212:29-38.

117. Carracedo A, Rousseau D, Douris N, Fernandez-Ruiz S, Martin-Martin N, Weiss D, Webster K, Adams AC, Vazquez-Chantada M, Martinez-Chantar $\mathrm{ML}$, et al. The promyelocytic leukemia protein is upregulated in conditions of obesity and liver steatosis. Int J Biol Sci. 2015;11:629-32.

118. Cheng X, Guo S, Liu Y, Chu H, Hakimi P, Berger NA, Hanson RW, Kao HY. Ablation of promyelocytic leukemia protein $(\mathrm{PML})$ re-patterns energy balance and protects mice from obesity induced by a Western diet. J Biol Chem. 2013;288:29746-59.

119. Chan JY, Chin W, Liew CT, Chang KS, Johnson PJ. Altered expression of the growth and transformation suppressor PML gene in human hepatocellular carcinomas and in hepatitis tissues. Eur J Cancer. 1998;34:1015-22.

120. Cheng $X$, Kao HY. Microarray analysis revealing common and distinct functions of promyelocytic leukemia protein (PML) and tumor necrosis factor alpha (TNFalpha) signaling in endothelial cells. BMC Genomics. 2012;13:453.

121. Kim MK, Yang S, Lee KH, Um JH, Liu M, Kang H, Park SJ, Chung JH. Promyelocytic leukemia inhibits adipogenesis, and loss of promyelocytic leukemia results in fat accumulation in mice. Am J Physiol Endocrinol Metab. 2011;301:E1130-42.

122. Maarifi G, Chelbi-Alix MK, Nisole S. PML control of cytokine signaling. Cytokine Growth Factor Rev. 2014;25:551-61.

123. Everett RD. DNA viruses and viral proteins that interact with PML nuclear bodies. Oncogene. 2001;20:7266-73.

124. Adamson AL, Kenney S. Epstein-barr virus immediate-early protein BZLF1 is SUMO-1 modified and disrupts promyelocytic leukemia bodies. J Virol. 2001;75:2388-99.

125. Boutell C, Cuchet-Lourenco D, Vanni E, Orr A, Glass M, McFarlane S, Everett RD. A viral ubiquitin ligase has substrate preferential SUMO targeted ubiquitin ligase activity that counteracts intrinsic antiviral defence. PLoS Pathog. 2011;7:e1002245.

126. Kelly C, Van Driel R, Wilkinson GW. Disruption of PML-associated nuclear bodies during human cytomegalovirus infection. J Gen Virol. 1995;76(Pt 11):2887-93.

127. Maroui MA, Pampin M, Chelbi-Alix MK. Promyelocytic leukemia isoform IV confers resistance to encephalomyocarditis virus via the sequestration of 3D polymerase in nuclear bodies. J Virol. 2011:85:13164-73.

128. Turelli P, Doucas V, Craig E, Mangeat B, Klages N, Evans R, Kalpana G, Trono D. Cytoplasmic recruitment of INI1 and PML on incoming HIV preintegration complexes: interference with early steps of viral replication. Mol Cell. 2001;7:1245-54.

129. Bonilla WV, Pinschewer DD, Klenerman P, Rousson V, Gaboli M, Pandolfi PP, Zinkernagel RM, Salvato MS, Hengartner H. Effects of promyelocytic leukemia protein on virus-host balance. J Virol. 2002;76:3810-8.

130. McLaughlin-Drubin ME, Munger K. Viruses associated with human cancer. Biochim Biophys Acta. 2008;1782:127-50.

131. Herzer K, Weyer S, Krammer PH, Galle PR, Hofmann TG. Hepatitis C virus core protein inhibits tumor suppressor protein promyelocytic leukemia function in human hepatoma cells. Cancer Res. 2005;65:10830-7.

132. Herzer K, Carbow A, Sydor S, Sowa JP, Biesterfeld S, Hofmann TG, Galle PR, Gerken G, Canbay A. Deficiency of the promyelocytic leukemia protein fosters hepatitis C-associated hepatocarcinogenesis in mice. PLOS ONE. 2012;7:e44474.

133. Day PM, Baker CC, Lowy DR, Schiller JT. Establishment of papillomavirus infection is enhanced by promyelocytic leukemia protein (PML) expression. Proc Natl Acad Sci USA. 2004;101:14252-7.

134. Lunardi A, Gaboli M, Giorgio M, Rivi R, Bygrave A, Antoniou M, Drabek D, Dzierzak E, Fagioli M, Salmena L, et al. A role for PML in innate immunity. Genes Cancer. 2011;2:10-9. 
135. Lo YH, Huang YW, Wu YH, Tsai CS, Lin YC, Mo ST, Kuo WC, Chuang YT, Jiang ST, Shih HM, Lai MZ. Selective inhibition of the NLRP3 inflammasome by targeting to promyelocytic leukemia protein in mouse and human. Blood. 2013;121:3185-94.

136. Geoffroy MC, Chelbi-Alix MK. Role of promyelocytic leukemia protein in host antiviral defense. J Interferon Cytokine Res. 2011;31:145-58.

137. El Bougrini J, Dianoux L, Chelbi-Alix MK. PML positively regulates interferon gamma signaling. Biochimie. 2011;93:389-98.

138. Ulbricht T, Alzrigat M, Horch A, Reuter N, von Mikecz A, Steimle V, Schmitt E, Kramer OH, Stamminger T, Hemmerich P. PML promotes MHC class II gene expression by stabilizing the class II transactivator. J Cell Biol. 2012;199:49-63.

139. El Asmi F, Maroui MA, Dutrieux J, Blondel D, Nisole S, Chelbi-Alix MK. Implication of PMLIV in both intrinsic and innate immunity. PLoS Pathog. 2014;10:e1003975.

140. Kim YE, Ahn JH. Positive role of promyelocytic leukemia protein in type I interferon response and its regulation by human cytomegalovirus. PLoS Pathog. 2015:11:e1004785.

141. Crowder C, Dahle O, Davis RE, Gabrielsen OS, Rudikoff S. PML mediates IFN-alpha-induced apoptosis in myeloma by regulating TRAIL induction. Blood. 2005;105:1280-7.

142. Carswell EA, Old LJ, Kassel RL, Green S, Fiore N, Williamson B. An endotoxin-induced serum factor that causes necrosis of tumors. Proc Natl Acad Sci USA. 1975;72:3666-70.

143. Wu W-S, Xu Z-X, Hittelman WN, Salomoni P, Pandolfi PP, Chang K-S. Promyelocytic leukemia protein sensitizes tumor necrosis factor $a$-induced apoptosis by inhibiting the NF-kB survival pathway. J Biol Chem. 2003;278:12294-304.

144. Wu WS, Xu ZX, Chang KS. The promyelocytic leukemia protein represses A20-mediated transcription. J Biol Chem. 2002;277:31734-9.

145. Hall MH, Magalska A, Malinowska M, Ruszczycki B, Czaban I, Patel S, Ambrozek-Latecka M, Zolocinska E, Broszkiewicz H, Parobczak K, et al. Localization and regulation of PML bodies in the adult mouse brain. Brain Struct Funct. 2016;221:2511-25.

146. Butler K, Martinez LA, Tejada-Simon MV. Impaired cognitive function and reduced anxiety-related behavior in a promyelocytic leukemia (PML) tumor suppressor protein-deficient mouse. Genes Brain Behav. 2013;12:189-202

147. Korb E, Wilkinson CL, Delgado RN, Lovero KL, Finkbeiner S. Arc in the nucleus regulates PML-dependent GluA1 transcription and homeostatic plasticity. Nat Neurosci. 2013;16:874-83.

148. Janer A, Martin E, Muriel MP, Latouche M, Fujigasaki H, Ruberg M, Brice A, Trottier Y, Sittler A. PML clastosomes prevent nuclear accumulation of mutant ataxin-7 and other polyglutamine proteins. J Cell Biol. 2006;174:65-76

149. Li W, Rich T, Watson CJ. PML: a tumor suppressor that regulates cell fate in mammary gland. Cell Cycle. 2009;8:2711-7.

150. Sargeant TJ, Lloyd-Lewis B, Resemann HK, Ramos-Montoya A, Skepper J, Watson CJ. Stat3 controls cell death during mammary gland involution by regulating uptake of milk fat globules and lysosomal membrane permeabilization. Nat Cell Biol. 2014;16:1057-68.

151. Ponente M, Campanini L, Cuttano R, Piunti A, Delledonne GA, Coltella N, Valsecchi R, Villa A, Cavallaro U, Pattini L, et al. PML promotes metastasis of triple-negative breast cancer through transcriptional regulation of HIF1A target genes. JCI Insight. 2017;2:e87380.

152. Bernardi R, Guernah I, Jin D, Grisendi S, Alimonti A, Teruya-Feldstein J, Cordon-Cardo C, Simon MC, Rafii S, Pandolfi PP. PML inhibits HIF-1alpha translation and neoangiogenesis through repression of mTOR. Nature. 2006;442:779-85

153. Lin YC, Lu LT, Chen HY, Duan X, Lin X, Feng XH, Tang MJ, Chen RH. SCP phosphatases suppress renal cell carcinoma by stabilizing PML and inhibiting mTOR/HIF signaling. Cancer Res. 2014;74:6935-46.
154. Dvorkina M, Nieddu V, Chakelam S, Pezzolo A, Cantilena S, Leite AP, Chayka O, Regad T, Pistorio A, Sementa AR, et al. A promyelocytic leukemia protein-thrombospondin-2 axis and the risk of relapse in neuroblastoma. Clin Cancer Res. 2016;22:3398-409.

155. Tang MK, Liang YJ, Chan JY, Wong SW, Chen E, Yao Y, Gan J, Xiao L, Leung $\mathrm{HC}$, Kung HF, et al. Promyelocytic leukemia (PML) protein plays important roles in regulating cell adhesion, morphology, proliferation and migration. PLOS ONE. 2013;8:e59477.

156. Fan JB, Arimoto K, Motamedchaboki K, Yan M, Wolf DA, Zhang DE. Identification and characterization of a novel ISG 15-ubiquitin mixed chain and its role in regulating protein homeostasis. Sci Rep. 2015;5:12704.

157. Huang YF, Wee S, Gunaratne J, Lane DP, Bulavin DV. Isg15 controls p53 stability and functions. Cell Cycle. 2014;13:2200-10.

158. Khalfin-Rabinovich Y, Weinstein A, Levi BZ. PML is a key component for the differentiation of myeloid progenitor cells to macrophages. Int Immunol. 2011;23:287-96.

159. Katome T, Namekata K, Naito T, Semba K, Guo X, Harada C, Harada T, Mitamura Y. Expression of promyelocytic leukemia protein and vascular endothelial growth factor in aqueous humor and vitreous fluid in patients with proliferative diabetic retinopathy. Diabetes Res Clin Pract. 2012;98:e9-11.

160. Yang L, Yeh SD, Xie S, Altuwaijri S, Ni J, Hu YC, Chen YT, Bao BY, Su CH, Chang C. Androgen suppresses PML protein expression in prostate cancer CWR22R cells. Biochem Biophys Res Commun. 2004;314:69-75.

161. Chan JY, Li L, Fan YH, Mu ZM, Zhang WW, Chang KS. Cell-cycle regulation of DNA damage-induced expression of the suppressor gene PML. Biochem Biophys Res Commun. 1997;240:640-6.

162. Nacerddine K, Lehembre F, Bhaumik M, Artus J, Cohen-Tannoudji M, Babinet C, Pandolfi PP, Dejean A. The SUMO pathway is essential for nuclear integrity and chromosome segregation in mice. Dev Cell. 2005:9:769-79.

163. Everett RD, Lomonte P, Sternsdorf T, van Driel R, Orr A. Cell cycle regulation of PML modification and ND10 composition. J Cell Sci. 1999;112:4581-8

164. Marcos-Villar L, Lopitz-Otsoa F, Gallego P, Munoz-Fontela C, GonzalezSantamaria J, Campagna M, Shou-Jiang G, Rodriguez MS, Rivas C. Kaposi's sarcoma-associated herpesvirus protein LANA2 disrupts PML oncogenic domains and inhibits PML-mediated transcriptional repression of the survivin gene. J Virol. 2009;83:8849-58.

165. Yang Q, Deng X, Lu B, Cameron M, Fearns C, Patricelli MP, Yates lii JR, Gray NS, Lee J-D. Pharmacological inhibition of BMK1 suppresses tumor growth through promyelocytic leukemia protein. Cancer Cell. 2010;18:258-67.

166. Guan D, Factor D, Liu Y, Wang Z, Kao HY. The epigenetic regulator UHRF1 promotes ubiquitination-mediated degradation of the tumor-suppressor protein promyelocytic leukemia protein. Oncogene. 2013;32:3819-28.

167. Guo A, Salomoni P, Luo J, Shih A, Zhong S, Gu W, Pandolfi PP. The function of PML in p53-dependent apoptosis. Nat Cell Biol. 2000;2:730-6.

\section{Submit your next manuscript to BioMed Central and we will help you at every step:}

- We accept pre-submission inquiries

- Our selector tool helps you to find the most relevant journal

- We provide round the clock customer support

- Convenient online submission

- Thorough peer review

- Inclusion in PubMed and all major indexing services

- Maximum visibility for your research

Submit your manuscript at www.biomedcentral.com/submit 